\title{
Oxygen Release and Surface Degradation of Li- and Mn-Rich Layered Oxides in Variation of the $\mathrm{Li}_{2} \mathrm{MnO}_{3}$ Content
}

\author{
Tobias Teufl, $\oplus^{1,2, *, z}$ Benjamin Strehle, ${ }^{2, *}$ Philipp Müller, ${ }^{1}$ Hubert A. Gasteiger, ${ }^{2, * *}$ \\ and Manuel A. Mendez ${ }^{1}$
}

${ }^{1}$ BASF SE Ludwigshafen, New Battery Materials and Systems, D-67056 Ludwigshafen, Germany
${ }^{2}$ Chair of Technical Electrochemistry, Department of Chemistry and Catalysis Research Center, Technical University of
Munich, D-85748 Garching, Germany

In this study, we will show how the oxygen release depends on the $\mathrm{Li}_{2} \mathrm{MnO}_{3}$ content of the material and how it affects the actual voltage fading of the material. Thus, we compared overlithiated NCMs $\left(\mathrm{x} \mathrm{Li}_{2} \mathrm{MnO}_{3} \bullet(1-\mathrm{x}) \mathrm{LiMeO}_{2} ; \mathrm{Me}=\mathrm{Ni}, \mathrm{Co}, \mathrm{Mn}\right)$ with $\mathrm{x}=$ $0.33,0.42$ and 0.50 , focusing on oxygen release and electrochemical performance. We could show that the oxygen release differs vastly for the materials, while voltage fading is similar, which leads to the conclusion that the oxygen release is a chemical material degradation, occurring at the surface, while voltage fading is a bulk issue of these materials. We could prove this hypothesis by HRTEM, showing a surface layer, which is dependent on the amount of oxygen released in the first cycles and leads to an increase of the charge-transfer resistance of these materials. Furthermore, we could quantitatively deconvolute capacity contributions from bulk and surface regions by $\mathrm{dQ} / \mathrm{dV}$ analysis and correlate them to the oxygen loss. As a last step, we compared the gassing to the base $\mathrm{NCM}\left(\mathrm{LiMeO}_{2}, \mathrm{Me}=\mathrm{Ni}, \mathrm{Co}, \mathrm{Mn}\right)$, showing that surface degradation follows a similar reaction pathway and can be easily modulated by controlling the amount of $\mathrm{Li}_{2} \mathrm{MnO}_{3}$.

(C) The Author(s) 2018. Published by ECS. This is an open access article distributed under the terms of the Creative Commons Attribution Non-Commercial No Derivatives 4.0 License (CC BY-NC-ND, http://creativecommons.org/licenses/by-nc-nd/4.0/), which permits non-commercial reuse, distribution, and reproduction in any medium, provided the original work is not changed in any way and is properly cited. For permission for commercial reuse, please email: oa @electrochem.org. [DOI: 10.1149/2.0691811jes]

(c) BY-NC-ND

Manuscript submitted June 15, 2018; revised manuscript received July 31, 2018. Published August 24, 2018. This was Paper 36 presented at the New Orleans, Louisiana, Meeting of the Society, May 28-June 1, 2017.

To face future issues, as global warming, air pollution, as well as the consumption of fossil fuels, an alternative is required to cover the future demand of energy and mobility in an environmentally friendly and sustainable way. In this context, lithium-ion batteries are viable options for large scale energy storage and for electric vehicles, as they have been used to power consumer electronics for many years. ${ }^{1,2}$ Since graphite is an excellent anode material at potentials of $\approx 0.1 \mathrm{~V}$ vs. $\mathrm{Li}^{+} / \mathrm{Li}$ with a roughly 2 -fold higher specific capacity of about $360 \mathrm{mAh} / \mathrm{g}$ compared to currently used cathode active materials (CAMs), many efforts have been undertaken to increase the specific capacity and energy density of CAMs. As first practical cathode active material Lithium-Cobalt-Oxide (LCO) was investigated by Goodenough et al. in the 1980 s, exhibiting a specific capacity of about 140 $\mathrm{mAh} / \mathrm{g}$ and having a layered structure composed of lithium and transition metal layers. ${ }^{3}$ As these layered structures showed good structural stability during lithium extraction and insertion, and therefore good capacity retention, many attempts have been undertaken to further develop alternative layered structures which would offer higher capacity. One promising attempt that led to the currently used Lithium-NickelCobalt-Manganese-Oxides (NCMs) is to change the occupancy of the transition metal layer by not using exclusively cobalt, but also introducing nickel and manganese into the transition metal layer; hereby it was found that nickel shows a high redox activity, while manganese helps to stabilize the structure during lithium extraction. ${ }^{4-6}$ By using different transition metals and metal compositions, a playground has been created that allows to tune the properties of the material: while initially a Ni:Co:Mn ratio of 1:1:1 was used (also referred to as NCM-111), trends nowadays favor the so-called Ni-rich NCMs, for example with a Ni:Co:Mn ratio of 8:1:1, which yield higher capacities at practicable potentials. ${ }^{6,7}$ However, it has been shown that all NCM materials show structural instabilities at high state-of-charge (SOC), i.e., at a high degree of delithiation, leading to oxygen release from the near-surface region accompanied by the formation of a resistive surface layer; ultimately, this leads to rapid capacity fading and limits the practical capacity of NCM materials to $<200 \mathrm{mAh} / \mathrm{g} .{ }^{8-10}$

\footnotetext{
*Electrochemical Society Member.

**Electrochemical Society Fellow.

${ }^{\text {zE} E-m a i l: ~ t o b i a s-m a x i m i l i a n . t e u f l @ b a s f . c o m ~}$
}

Therefore, in the 2000s the concept of lithium- and manganeserich NCM materials was investigated by preparing a $\mathrm{Li}_{2} \mathrm{MnO}_{3}$ domain within an NCM material in a certain composition, leading to $\mathrm{x} \mathrm{Li}_{2} \mathrm{MnO}_{3} \bullet(1-\mathrm{x}) \mathrm{LiMeO}_{2}(\mathrm{Me}=\mathrm{Ni}, \mathrm{Co}, \mathrm{Mn})$, also referred to as High-Energy NCM (HE-NCM), with which high reversible capacities of $\approx 250 \mathrm{mAh} / \mathrm{g}$ can be achieved. ${ }^{11}$ However, these materials exhibit serious issues that so far has hindered its commercialization, such as a decrease of the average discharge voltage over extended charge/discharge cycling (commonly referred to as voltage fading), a large hysteresis between charge and discharge voltage, as well as high impedance. ${ }^{12-14}$ Since the discovery of this class of materials, researchers have been trying to find an explanation for these high reversible capacities, as the capacities exceed the theoretical capacity limit that could be explained by the classical view of transition metal cation redox. Initially, it was thought that during the first cycle activation plateau at $\approx 4.5 \mathrm{~V}$ vs. $\mathrm{Li}^{+} / \mathrm{Li}$ an electrochemical activation of redox inactive $\mathrm{Li}_{2} \mathrm{MnO}_{3}$ would take place, leading to a release of bulk lattice oxygen and to an electrochemically active $\mathrm{LiMnO}_{2}$ phase which could charge compensate $\mathrm{Li}$ extraction to capacities $>200 \mathrm{mAh} / \mathrm{g} .{ }^{15-18}$ This oxygen release was ascribed to cause strong structural changes within the bulk material, ultimately leading to a layered-to-spinel transformation of the particles. This transformation of the bulk material was believed to lead to the HE-NCM specific phenomena such as voltage fading and hysteresis. ${ }^{12,19-22}$ However, this activation was suggested to be accompanied by an oxygen release from the bulk of the material, which was suggested from XRD data by $\mathrm{Lu}$ et al. in $2002 .{ }^{19,20}$ At first sight, this seemed consistent with the mass spectrometrically detected $\mathrm{O}_{2}$ and $\mathrm{CO}_{2}$ evolution starting during the activation plateau, which was interpreted to indicate the release of $\mathrm{Li}_{2} \mathrm{O}$ from the bulk of the material during activation and accompanying structural changes within the bulk material. ${ }^{15,17,18,23,24}$ However, the exact quantification of the released oxygen by Strehle et al. and Luo et al. revealed that the amount of released oxygen is an order of magnitude too low to be consistent with the assumed electrochemical oxygen release $\mathrm{e}^{25,26}$ and also that the $\mathrm{O}_{2}$ evolution does not start until right after the activation plateau (only $<10 \mu \mathrm{mol}_{\mathrm{O} 2} / \mathrm{g}_{\mathrm{AM}}$ during the plateau, but $>100 \mu \mathrm{mol}_{\mathrm{O} 2} / \mathrm{g}_{\mathrm{AM}}$ following thereafter; shown by Strehle et al.). ${ }^{25}$ Both observations suggested that the observed oxygen release cannot be ascribed to a loss of oxygen from the bulk of the material, but that the oxygen is only being released from the near-surface 
region of the HE-NCM material. ${ }^{25}$ While this contradicted most of the literature on the mechanistics of the HE-NCM activation process, it was in accordance with the conclusions drawn by earlier work based on careful XRD, neutron diffraction, and high-resolution transmission electron microscopy. ${ }^{27-29}$

Thus, more recent studies propose that bulk and surface of these overlithiated materials show distinctly different properties, rationalized by a bulk-shell model..$^{25,27-29}$ It has been suggested that oxygen release takes places in near-surface region, leading to a chemical layered-to-spinel transformation and a concomitant impedance buildup by the formed resistive surface layer. This phenomenon has also been shown to be one of the main fading mechanisms for traditional NCM materials. ${ }^{10,30}$ In contradiction to the bulk oxygen release, the recent literature gives strong evidence that reversible anionic oxygen redox participation in the bulk material can serve for charge compensation and therefore explain the high reversible capacities within this class of materials. ${ }^{31-34}$ Therefore, it is suggested that high degrees of delithiation and reversible oxygen redox trigger reversible and irreversible transition metal migration within the bulk material, leading to voltage fading and to the large charge/discharge voltage hysteresis due to the hindered lithium diffusion within the bulk material. ${ }^{14,35-38}$ In contradiction to the hypothesis of bulk oxygen release and bulk structural transformation, recent studies give clear evidence that the bulk structure is preserved, while a relatively small fraction of transition metals (about $10 \%$ over 100 cycles) ${ }^{35}$ migrate reversibly and over extended charge/discharge cycling irreversibly between the transition metal and the lithium layers, leading to changes of the bulk material thermodynamics like the charge and discharge potentials as well as to the observed voltage fading. ${ }^{25,35}$

In this study, we will examine the effect of oxygen release onto the bulk and the surface structure of HE-NCM and correlate it with the macroscopic electrochemical performance of the material. These studies will be conducted with HE-NCM materials with different amounts of the $\mathrm{Li}_{2} \mathrm{MnO}_{3}$ phase $(\mathrm{x}=0.33,0.42$ and 0.50 if referenced to $\mathrm{x} \mathrm{Li}_{2} \mathrm{MnO}_{3} \bullet(1-\mathrm{x}) \mathrm{LiMeO}_{2}$ ), comparing the materials in terms of their oxygen release, their half- and full-cell performance as well as their impedance growth. These data will be complemented with high-resolution transmission electron microcopy (HRTEM) analysis of pristine and charge/discharge cycled materials. By on-line electrochemical mass spectrometry (OEMS) and HRTEM we prove that oxygen release above $4.6 \mathrm{~V}$ vs. $\mathrm{Li}^{+} / \mathrm{Li}$ leads to a restructuration of the near-surface region, the extent of which increases with increasing over-lithiation and with increasing amounts of oxygen released during the first few cycles. Furthermore, while large differences are observed in the amount of oxygen released for the different materials, their electrochemical performance as well as their voltage fading behavior does not correlate with the extent of oxygen release. Thus, we propose that oxygen release does not have an influence on the bulk properties of HE-NCM, but rather affects the extent of surface restructuration/degradation.

\section{Experimental}

Electrode preparation.-HE-NCM with the compositions $0.33 \mathrm{Li}_{2} \mathrm{MnO}_{3} \bullet 0.67 \mathrm{LiMeO}_{2}, 0.42 \mathrm{Li}_{2} \mathrm{MnO}_{3} \bullet 0.58 \mathrm{LiMeO}_{2}$, and $0.50 \mathrm{Li}_{2} \mathrm{MnO}_{3} \bullet 0.50 \mathrm{LiMeO}_{2}$ was obtained from BASF SE (Germany) and synthesized by the same procedure. While the exact Ni:Co:Mn ratio of the base $\mathrm{NCM}$ cannot be disclosed, the $\mathrm{LiMeO}_{2}$ domain was held constant for all materials used in this study, while only the amount of $\mathrm{Li}_{2} \mathrm{MnO}_{3}$ was varied from 0.00 up to 0.50 . The sum formula for the materials was $\mathrm{x} \mathrm{Li}_{2} \mathrm{MnO}_{3} \bullet(1-\mathrm{x}) \mathrm{LiMeO}_{2}(\mathrm{x}=0.00,0.33,0.42$, $0.50)$, whereby the $\mathrm{x}=0.42$ material is identical what that used by Strehle et al. ${ }^{25}$ For coin cell testing, inks for cathode electrode preparation consisted of $92.5 \mathrm{wt} \%$ HE-NCM (BASF SE, Germany), $3.5 \mathrm{wt} \%$ polyvinylidene-fluoride binder (PVDF, Solef 5130, Solvay, Belgium), $2 \mathrm{wt} \%$ conductive carbon (Super-C65, Timcal, Switzerland; BET area of $\approx 65 \mathrm{~m}^{2} / \mathrm{g}$ ), and $2 \mathrm{wt} \%$ graphite (SFG6L, Timcal, Switzerland; BET area of $\approx 17 \mathrm{~m}^{2} / \mathrm{g}$ ). The materials were dispersed in N-methyl pyrrolidine (NMP, anhydrous, Sigma-Aldrich, USA) and coated onto aluminum foil $(16 \mu \mathrm{m})$. Dried electrodes were calendered to a den- sity of $2.3 \mathrm{~g} / \mathrm{cm}^{3}$, calandered electrodes had final electrode thickness of $20 \mu \mathrm{m}$. For electrochemical testing, electrodes with a diameter of $14 \mathrm{~mm}$ were punched out, ending up with an active material loading of $\approx 6.5 \mathrm{mg} / \mathrm{cm}^{2}$, corresponding to $\approx 1.6 \mathrm{mAh} / \mathrm{cm}^{2}$, based on a nominal reversible capacity of $250 \mathrm{mAh} / \mathrm{g}$.

Electrodes for OEMS measurements were prepared by dispersing $96 \mathrm{wt} \% \mathrm{HE}-\mathrm{NCM}$ or the base $\mathrm{NCM}$ without $\mathrm{Li}_{2} \mathrm{MnO}_{3}$ (BASF SE, Germany), 2 wt $\%$ conductive carbon (Super-C65, Timcal, Switzerland), and 2 wt\% PVDF binder (Kynar HSV 900, Arkema, France) in NMP (anhydrous, Sigma-Aldrich, USA). A high solid content of $71 \%$ for the slurry was chosen to enable coating onto a porous stainlesssteel mesh (SS316, aperture $26 \mu \mathrm{m}$, wire diameter $25 \mu \mathrm{m}$, The Mesh Company Ltd., UK). The slurry was coated with a wet film thickness of $20 \mu \mathrm{m}$ onto the stainless-steel mesh, yielding a HE-NCM loading of $\approx 8.5 \mathrm{mg} / \mathrm{cm}^{2}$, corresponding to $\approx 2.1 \mathrm{mAh} / \mathrm{cm}^{2}$. Electrodes for OEMS experiments were punched out with a diameter of $15 \mathrm{~mm}$ and compressed for $20 \mathrm{~s}$ with 2.5 tons.

Graphite electrodes were commercial electrodes with a graphite loading of $\approx 6.7 \mathrm{mg} / \mathrm{cm}^{2}$, corresponding to $\approx 2.4 \mathrm{mAh} / \mathrm{cm}^{2}$ (based on a theoretical capacity of $360 \mathrm{mAh} / \mathrm{g}$ ); for electrochemical testing, graphite electrodes with a diameter of $15 \mathrm{~mm}$ were punched out. All anode and cathode electrodes were dried overnight under vacuum in an oven within the glove box $\left(\mathrm{O}_{2}, \mathrm{H}_{2} \mathrm{O}<0.1 \mathrm{ppm}\right.$, MBraun, Germany) at $120^{\circ} \mathrm{C}$ and were not exposed to air after the drying procedure. For some experiments, graphite anodes were preformed in coin half-cells: cells were cycled for two cycles with a discharge rate of $\mathrm{C} / 15$ down to $0.025 \mathrm{~V} \mathrm{vs}$. $\mathrm{Li}^{+} / \mathrm{Li}$ followed by a $1 \mathrm{~h} \mathrm{CV}$ step at this potential and a subsequent charge at $\mathrm{C} / 15$ up to $1.5 \mathrm{~V}$ vs. $\mathrm{Li}^{+} / \mathrm{Li}$; then, the cells were disassembled at $1.5 \mathrm{~V}$ in a glove box $\left(\mathrm{O}_{2}, \mathrm{H}_{2} \mathrm{O}<0.1 \mathrm{ppm}\right.$, MBraun, Germany). These preformed graphite electrodes were used for full-cell assembly without any further washing step.

On-line electrochemical mass spectrometry (OEMS).--For OEMS experiments, electrodes coated onto a stainless-steel mesh (see above) were used to have a porous medium as current collector in order to allow diffusion from the electrode to the capillary. ${ }^{25}$ For OEMS measurements a custom-made cell is used; the cell design as well as the OEMS setup were reported previously. ${ }^{39}$ OEMS cells were assembled with Li metal counter electrode, two porous polyolefin separators (2500, Celgard, USA), a HE-NCM or NCM working electrode and $120 \mu \mathrm{l}$ of electrolyte composed of FEC:DEC (2:8 g:g) and $1 \mathrm{M} \mathrm{LiPF}_{6}$ (BASF SE, Germany). The cells were connected to the mass spectrometer, held for $4 \mathrm{~h}$ at $\mathrm{OCV}$ (open circuit voltage), and then charged to $4.8 \mathrm{~V} \mathrm{vs.} \mathrm{Li}^{+} / \mathrm{Li}$ at a $\mathrm{C} / 10$ rate, followed by a $1 \mathrm{~h} \mathrm{CV}$ step at $4.8 \mathrm{~V}$ vs. $\mathrm{Li}^{+} / \mathrm{Li}$; the discharge to $2.0 \mathrm{~V}$ vs. $\mathrm{Li}^{+} / \mathrm{Li}$ and the second charge/discharge cycle were conducted at $\mathrm{C} / 5$ rate between $4.8 \mathrm{~V}$

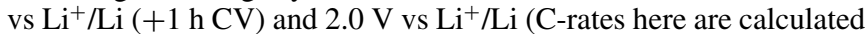
based on a nominal capacity of $250 \mathrm{mAh} / \mathrm{g}$ ). For quantification of the mass spectrometer currents, a calibration gas containing $\mathrm{H}_{2}, \mathrm{O}_{2}, \mathrm{CO}_{2}$, $\mathrm{C}_{2} \mathrm{H}_{4}$ (each 2000 ppm) in Argon (Linde AG, Germany) was used. All currents were normalized to the current at $\mathrm{m} / \mathrm{z}=36$ (Ar isotope) in order to correct for effects of minor pressure and temperature deviations, and afterwards the currents $\mathrm{m} / \mathrm{z}=32\left(\mathrm{O}_{2}\right)$ and $\mathrm{m} / \mathrm{z}=44\left(\mathrm{CO}_{2}\right)$ were converted into gas concentration.

Electrochemical characterization.-Galvanostatic cycling was carried out in 2032-type coin-cells (Hohsen Corp., Japan) at $25^{\circ} \mathrm{C}$ in a temperature controlled oven (Binder, Germany) and using a battery cycler (Series 4000, Maccor, USA). Half-cells were assembled in an argon filled glove box $\left(\mathrm{O}_{2}, \mathrm{H}_{2} \mathrm{O}<0.1 \mathrm{ppm}\right.$, MBraun, Germany) using a Li metal anode with a diameter of $17 \mathrm{~mm}$, three glass fiber separators (glass microfiber, GF/A, VWR, Germany), and an HE-NCM cathode (coated on $\mathrm{Al}$ current collector) with a diameter of $14 \mathrm{~mm}$. The cells were filled with $120 \mu \mathrm{L}$ electrolyte (FEC:DEC (2:8 g:g) with $1 \mathrm{M} \mathrm{LiPF}_{6}$; BASF SE, Germany). For impedance measurements in symmetrical cells, charge/discharge cycled half-cells were charged to $50 \%$ SOC in the final cycle (based on the preceding complete chargedischarge cycle) and afterwards the cathodes were harvested in an argon filled glove box. Subsequently, two harvested cathodes from cells cycled with the same procedure were reassembled for impedance 
measurements into a symmetric coin cell with one thick glass fiber separator (300 $\mu \mathrm{m}$ thickness; glass microfiber filter, GF/D, VWR, Germany) and $95 \mu \mathrm{L}$ of the same FEC:DEC electrolyte. For fullcell experiments in 2032 coin-cells, a graphite anode with a diameter of $15 \mathrm{~mm}$ and a cathode with a diameter of $14 \mathrm{~mm}$ were assembled with one polyethylene separator (2500, Celgard, USA) and with $14 \mu \mathrm{L}$ of electrolyte based on FEC:DEC with $1 \mathrm{M} \mathrm{LiPF}_{6}$ with an additional confidential co-solvent to improve full-cell cycling stability. For proof of reproducibility, at least two independent measurements were carried out and the here presented cycling data show the average values while the error bars reflect the maximum and minimum of the measured values.

All cells were allowed to rest for 2 hours prior to electrochemical testing and C-rates are referenced to a nominal capacity of $250 \mathrm{mAh} / \mathrm{g}$. For half-cells, the first activation cycle was conducted at $\mathrm{C} / 10$ up to $4.8 \mathrm{~V}$, followed by a $1 \mathrm{~h} \mathrm{CV}$-step at this potential and a discharge at $\mathrm{C} / 5$ to $2.0 \mathrm{~V}$. The second charge/discharge cycle was conducted at $\mathrm{C} / 5$ and also charged up to $4.8 \mathrm{~V}$, followed by $1 \mathrm{~h} \mathrm{CV}$-step at $4.8 \mathrm{~V}$ and a discharge at $\mathrm{C} / 5$ to $2.0 \mathrm{~V}$ (up to this point identical with the OEMS cycling procedure). The subsequent charge/discharge cycles at $\mathrm{C} / 5$ had a reduced upper cutoff potential of $4.7 \mathrm{~V}$ without a $\mathrm{CV}$-step and the same lower cutoff potential of $2.0 \mathrm{~V}$ (CC/CC charge/discharge procedure).

Full-cells were activated in the first cycle at a C-rate of $\mathrm{C} / 15$ to $4.7 \mathrm{~V}$ (corresponding to $\approx 4.8 \mathrm{~V} \mathrm{vs}$. $\mathrm{Li}^{+} / \mathrm{Li}$, as in the half-cell and OEMS measurements), followed by a 1-hour CV-step at this potential (CCCV charge), and then discharged at $\mathrm{C} / 15$ to $2.0 \mathrm{~V}$ (CC); in subsequent cycles, the upper cutoff and $\mathrm{CV}$-step potential were reduced to $4.6 \mathrm{~V}$. Afterwards 4 cycles at $\mathrm{C} / 10$ were applied (CCCV), followed by a rate test for which the cell was charged/discharged for 3 cycles each at $0.2 \mathrm{C}(\mathrm{CCCV}) / 0.5 \mathrm{C}(\mathrm{CC}), 0.5 \mathrm{C}(\mathrm{CCCV}) / 1 \mathrm{C}(\mathrm{CC}), 0.5 \mathrm{C}$ $(\mathrm{CCCV}) / 2 \mathrm{C}(\mathrm{CC}), 0.5 \mathrm{C}(\mathrm{CCCV}) / 3 \mathrm{C}(\mathrm{CC})$, whereby all $\mathrm{CV}$-steps were terminated after $1 \mathrm{~h}$ or when the current decreased below $0.01 \mathrm{C}$. The rate test was followed by 250 cycles with a charge rate of $0.5 \mathrm{C}(\mathrm{CCCV})$ and a discharge rate of $1 \mathrm{C}(\mathrm{CC})$, the $\mathrm{CV}$-step defined as above.

High-resolution transmission electron microscopy (HRTEM).Cathodes for HRTEM measurements were obtained from half-cell coin-cells which had been cycled at $\mathrm{C} / 5$ for 2 or 50 cycles (see above for cell assembly and half-cell cycling procedure). The electrodes were harvested at $0 \%$ SOC (cells discharged to $2.0 \mathrm{~V}$ ), corresponding to a fully lithiated cathode material. After cycling, cathodes were harvested in an argon filled glove-box and then washed for 5 minutes first in an FEC:DEC (2:8 g:g) solvent mixture and then in pure DEC (BASF SE, Germany). Subsequently, the electrodes were dried overnight at room temperature inside the glove box.

Samples for transmission electron microscopy (TEM) were prepared by focused ion beam (FIB) milling using a Strata 400 dualbeam machine (FEI Company, Hillsboro, USA). Samples were immediately imaged at $200 \mathrm{keV}$ by HRTEM on FEI Tecnai G20 and FEI Osiris microscopes. The local crystal structure of oriented crystallites was analyzed by Fourier-analysis of the images using the Digital Micrograph software (Gatan, Pleasanton, USA: version 2.11).

\section{Results}

Electrochemical activation plateau.-Table I lists the different HE-NCM and NCM materials by their compositions, given as $\mathrm{x} \mathrm{Li}_{2} \mathrm{MnO}_{3} \bullet(1-\mathrm{x}) \mathrm{LiMeO}_{2}(\mathrm{Me}=\mathrm{Ni}, \mathrm{Co}, \mathrm{Mn})$ with $\mathrm{x}=0.00,0.33$, 0.42 and 0.50 . The shown total theoretical capacities $(\mathrm{Q})$ are calculated for a theoretical complete delithiation using Faraday's law:

$$
\mathrm{Q}=\frac{n_{L i} F}{M}
$$

with $\mathrm{F}$ being the Faraday constant (96485 As/mol), M being the molar mass of the (HE-)NCM, and $\mathrm{n}_{\mathrm{Li}}$ being the moles of lithium per mol of (HE-)NCM. Furthermore, the fraction of the capacity arising from the NCM domain and from the $\mathrm{Li}_{2} \mathrm{MnO}_{3}$ domain can be calculated individually from the given stoichiometry and molecular weight and is also shown in Table I. From these results, one can see that higher

\begin{abstract}
Table I. Chemical formulas/compositions, theoretical capacity and BET surface areas for materials with $\mathrm{Li}_{2} \mathrm{MnO}_{3}$ content of 0.00 , $0.33,0.42$ and $0.50 ; \mathrm{Li}_{2} \mathrm{MnO}_{3}$ was varied with the same $\mathrm{LiMeO}_{2}$ component, ending up in a constant $\mathrm{Ni}$ :Co ratio and a variation in the amount of $\mathrm{Li}$ and $\mathrm{Mn}$ for the different compositions. The total theoretical capacity is calculated for $100 \%$ delithiation of the material, according to Equation 1; furthermore, shown are the nominal theoretical capacities of the $\mathrm{LiMeO}_{2}$ and the $\mathrm{Li}_{2} \mathrm{MnO}_{3}$ domains.
\end{abstract}

Theoretical capacity $[\mathrm{mAh} / \mathrm{g}]$

\begin{tabular}{cllll} 
Composition & Total & $\mathrm{LiMeO}_{2}$ & $\mathrm{Li}_{2} \mathrm{MnO}_{3}$ & $\begin{array}{c}\text { BET } \\
{\left[\mathrm{m}^{2} / \mathrm{g}\right]}\end{array}$ \\
\hline $0.00 \mathrm{Li}_{2} \mathrm{MnO}_{3} \bullet 1.00 \mathrm{LiMeO}_{2}$ & 279 & 279 & 0 & 0.5 \\
$0.33 \mathrm{Li}_{2} \mathrm{MnO}_{3} \bullet 0.67 \mathrm{LiMeO}_{2}$ & 346 & 174 & 172 & 6.5 \\
$0.42 \mathrm{Li}_{2} \mathrm{MnO}_{3} \bullet 0.58 \mathrm{LiMeO}_{2}$ & 363 & 148 & 215 & 6.5 \\
$0.50 \mathrm{Li}_{2} \mathrm{MnO}_{3} \bullet 0.50 \mathrm{LiMeO}_{2}$ & 377 & 126 & 251 & 6.0
\end{tabular}

$\mathrm{Li}_{2} \mathrm{MnO}_{3}$ contents lead to a higher share of capacity arising from the $\mathrm{Li}_{2} \mathrm{MnO}_{3}$ domain, but also the theoretical total capacity of the overall compound can be increased substantially with increasing lithium content. Also shown in Table I are the BET areas, which are essentially identical for the HE-NCM materials, but more than an order of magnitude lower for the NCM material. Therefore, for better comparability, gas evolution rates from OEMS experiments will be also normalized to the BET area (in units of $\mu \mathrm{mol} / \mathrm{m}^{2}$ ).

Figure 1 depicts the first cycle activation for all three compositions in half-cells, showing the first cycle charge-discharge curves
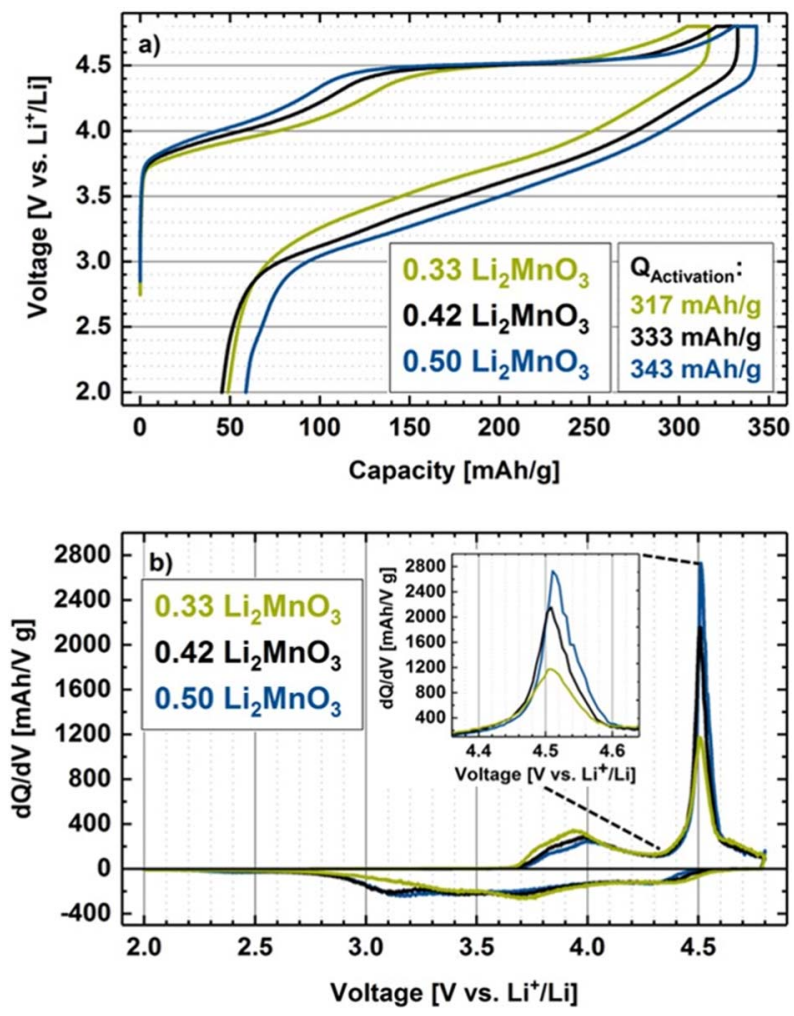

Figure 1. (a) Voltage vs. capacity for the first activation cycle in half-cells of HE-NCM with $0.33,0.42$, and $0.50 \mathrm{Li}_{2} \mathrm{MnO}_{3}$ content (see Table I); the first charge capacity $\mathrm{Q}_{\text {Activation }}$ is given in the figure. (b) Corresponding $\mathrm{dQ} / \mathrm{dV}$ plots, show an increasing peak at $4.5 \mathrm{~V}$ with increasing $\mathrm{Li}_{2} \mathrm{MnO}_{3}$ contents (the inset is a zoom into the $4.5 \mathrm{~V}$ region). Cells were activated with metallic$\mathrm{Li}$ as counter electrode at $\mathrm{C} / 10$ up to $4.8 \mathrm{~V}$ followed by a $1 \mathrm{~h} \mathrm{CV}$-step at $4.8 \mathrm{~V}$ and then discharged at $\mathrm{C} / 5$ to $2.0 \mathrm{~V}$ at $25^{\circ} \mathrm{C}$ in FEC:DEC (2:8 g:g) with $1 \mathrm{M} \mathrm{LiPF}_{6}$. 
in Figure 1a and the corresponding dQ/dV plot in Figure $1 b$, both showing a longer activation plateau and a higher amount of capacity in this plateau with increasing $\mathrm{Li}_{2} \mathrm{MnO}_{3}$ content. The first charge capacities are given in Figure 1a, reaching $317 \mathrm{mAh} / \mathrm{g}$ for a $\mathrm{Li}_{2} \mathrm{MnO}_{3}$ content of $0.33,333 \mathrm{mAh} / \mathrm{g}$ for $0.42 \mathrm{Li}_{2} \mathrm{MnO}_{3}$, and $343 \mathrm{mAh} / \mathrm{g}$ for $0.50 \mathrm{Li}_{2} \mathrm{MnO}_{3}$. Comparing the measured capacities from Figure 1 to the total theoretical capacities listed in Table I, the apparent degree of delithiation is $92 \%$ for the materials with 0.33 and $0.42 \mathrm{Li}_{2} \mathrm{MnO}_{3}$ and $91 \%$ for the material with $0.50 \mathrm{Li}_{2} \mathrm{MnO}_{3}$. While the degree of delithiation is similar for different $\mathrm{Li}_{2} \mathrm{MnO}_{3}$ contents, one should note that delithiation beyond $90 \%$ of the overall amount of lithium is unique for this class of materials and cannot be achieved for classical NCM materials without irreversibly destroying the material. ${ }^{10}$ However, this high delithiation cannot be explained by only taking cationic redox into account, given that $\mathrm{Mn}^{\mathrm{IV}}$ in $\mathrm{Li}_{2} \mathrm{MnO}_{3}$ is redox inactive. Therefore, it is clear that another mechanism is responsible for charge compensation. While some groups expect electrochemical activation of $\mathrm{Li}_{2} \mathrm{MnO}_{3}$ to $\mathrm{MnO}_{2}$ accompanied by bulk oxygen release, ${ }^{11}$ more recent publications give strong evidence that anionic oxygen redox might serve for charge compensation at high delithiation. ${ }^{26,31-33}$ The specific role of oxygen release HE-NCM particularly during the first activation cycle will be analyzed and discussed later on.

Focusing now on the quantitative effect of the $\mathrm{Li}_{2} \mathrm{MnO}_{3}$ on the capacity in the activation plateau, we defined the capacity gained during the plateau as the capacity gained between $4.40 \mathrm{~V}$ and $4.60 \mathrm{~V}$. The thus obtained capacities during the activation plateau are $116 \mathrm{mAh} / \mathrm{g}$ for $0.33 \mathrm{Li}_{2} \mathrm{MnO}_{3}, 159 \mathrm{mAh} / \mathrm{g}$ for $0.42 \mathrm{Li}_{2} \mathrm{MnO}_{3}$, and $190 \mathrm{mAh} / \mathrm{g}$ for the $0.50 \mathrm{Li}_{2} \mathrm{MnO}_{3}$ content, showing a clear correlation between the $\mathrm{Li}_{2} \mathrm{MnO}_{3}$ content and the activation plateau capacity. ${ }^{40}$ On the other hand, Figure 1a shows also that the capacity loss during the first discharge increases with increasing $\mathrm{Li}_{2} \mathrm{MnO}_{3}$ content, resulting in a comparable first-cycle irreversible capacity loss of 49 $\mathrm{mAh} / \mathrm{g}$ for 0.33 and $46 \mathrm{mAh} / \mathrm{g}$ for $0.42 \mathrm{Li}_{2} \mathrm{MnO}_{3}$, while the HE-NCM with the higher $0.50 \mathrm{Li}_{2} \mathrm{MnO}_{3}$ content shows a much higher value of $60 \mathrm{mAh} / \mathrm{g}$. In the discussion section, we will examine in detail the possible origins and explanations for this high irreversible capacity loss during activation, and how it influences the actual full-cell performance of the material.

Effect of the activation in full-cells.-For further analysis of the high irreversible capacity during the first charge/discharge cycle of HE-NCMs, full-cells were assembled, in the same way as the halfcells discussed in Figure 1, using a preformed graphite counter electrode instead of a lithium counter electrode. The graphite electrode was preformed in the same electrolyte in order to eliminate anode SEI losses (detailed information can be found in the experimental section). The upper cutoff potential was lowered from $4.8 \mathrm{~V}$ for the half-cells to $4.7 \mathrm{~V}$ in the full-cells, so that the upper cutoff potential of the cathode corresponded to $\approx 4.8 \mathrm{~V}$ vs. $\mathrm{Li}^{+} / \mathrm{Li}$ in both cases. Figure 2 a shows the corresponding first charge/discharge potential profiles for the different HE-NCMs. Comparable first-cycle irreversible capacities can be observed for the full-cells with preformed graphite electrodes and the Li metal half-cells (see Table II). By using preformed graphite electrodes, a capacity loss caused by the graphite anode is not expected, as a preformed SEI already exists which should prevent further electrolyte decomposition.

After the first cycle, the discharged cells were disassembled and the graphite anodes were harvested in order to determine the amount of cyclable lithium present in the graphite anode in the discharged HE-NCM//graphite full-cell. This was done by assembling half-cells with the harvested graphite electrodes with lithium counter electrodes and discharging them to $1.5 \mathrm{~V}$ at $0.1 \mathrm{C}$ in order to obtain the residual capacity in the graphite anodes, whereby this value was normalized to the mass of the cathode that was used during the full-cell activation, providing comparable results for the different cathode materials. Figure $2 \mathrm{~b}$ shows that the residual capacity in the graphite anodes depends on the $\mathrm{Li}_{2} \mathrm{MnO}_{3}$ content of the cathode used during full-cell activation, and as one might expect, a higher $\mathrm{Li}_{2} \mathrm{MnO}_{3}$ content leads to a higher residual capacity stored in the anode. Table II compares the
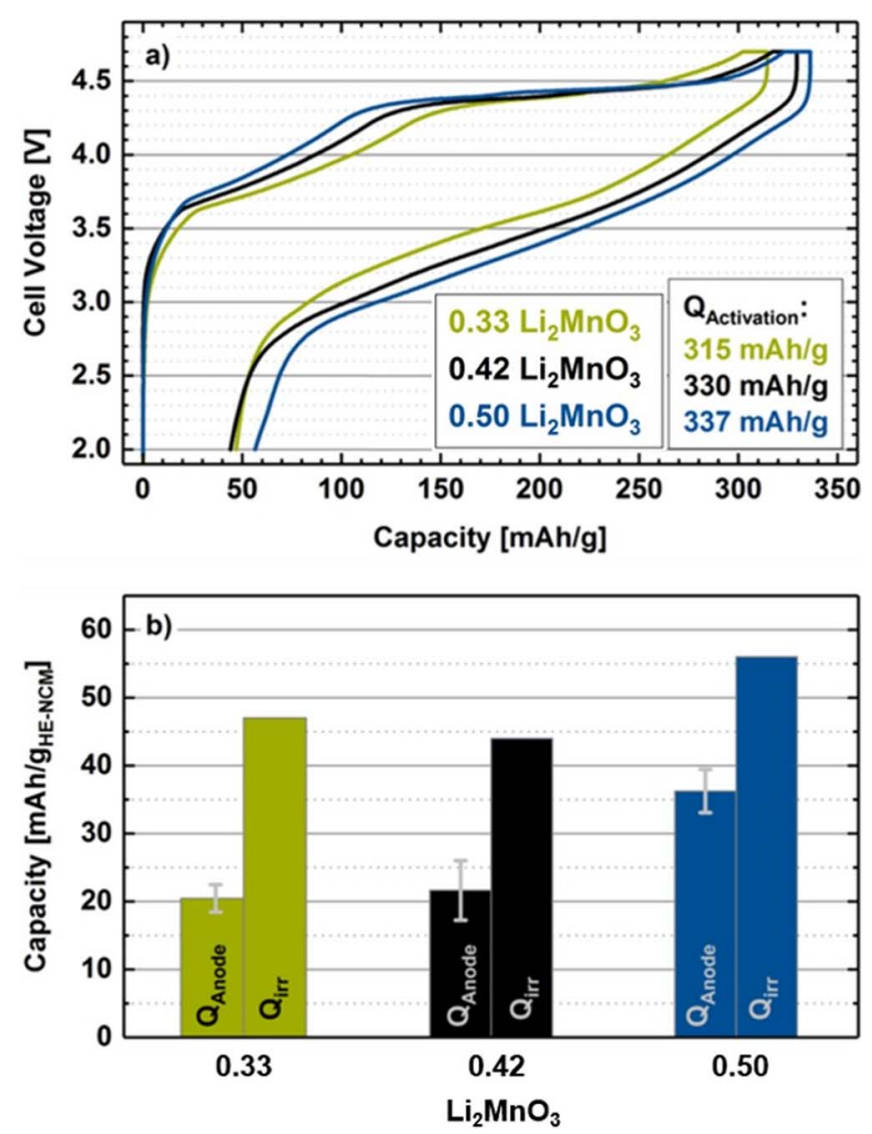

Figure 2. (a) Voltage curves for the first activation cycle in a full-cell of HE-NCM with $0.33,0.42$, and $0.50 \mathrm{Li}_{2} \mathrm{MnO}_{3}$ content (see Table I), using preformed graphite anodes (see experimental section). (b) Residual capacity of the preformed graphite anodes after the first charge/discharge cycle $\left(\mathrm{Q}_{\text {Anode }}\right)$, obtained from the delithiation of harvested graphite anodes in halfcells to $1.5 \mathrm{~V}$ at $\mathrm{C} / 10$ (referenced to the cathode loading), as well as the irreversible first-cycle capacities $\left(\mathrm{Q}_{\text {irr }}\right)$ derived from Figure $2 \mathrm{a}$ (error bars for the residual capacities are derived from two independent measurements). Fullcells were charged at $\mathrm{C} / 10$ up to $4.7 \mathrm{~V}$ followed by a $1 \mathrm{~h} \mathrm{CV}$-step at $4.7 \mathrm{~V}$ and then discharged at $\mathrm{C} / 5$ to $2.0 \mathrm{~V}$ at $25^{\circ} \mathrm{C}$ in FEC:DEC (2:8 g:g) with $1 \mathrm{MLiPF}_{6}$

first-cycle irreversible capacities measured during full-cell and halfcell activation as well as the residual capacity stored in the graphite anodes. From this it can be concluded that a higher first-cycle irreversible capacity leads to a higher amount of cyclable lithium within the graphite anode. In other words, a high irreversible capacity during the first charge does not necessarily mean that a high amount of lithium is lost irreversibly, but rather that after the HE-NMC activation not all of the extracted lithium can be reinserted into the cathode active

Table II. First-cycle irreversible capacities $\left(Q_{i r r}\right)$ during the first charge/discharge cycle for $\mathrm{HE}$-NCMs with different $\mathrm{Li}_{2} \mathrm{MnO}_{3}$ content, taken from Figure 1a and Figure 2a, respectively. Also, the residual capacity obtained from preformed graphite anodes shown in Figure $2 \mathrm{~b}$ is compared to the first-cycle irreversible capacity loss, showing an offset of $\approx 20-27 \mathrm{mAh} / \mathrm{g}$.

$$
\mathrm{Q}_{\text {irr }}[\mathrm{mAh} / \mathrm{g}]
$$
$\mathrm{Li}_{2} \mathrm{MnO}_{3} \quad$ Half-cell Full-cell preformed graphite $[\mathrm{mAh} / \mathrm{g}]$

$\begin{array}{llll}0.33 & 49 & 47 & 20 \\ 0.42 & 46 & 44 & 22 \\ 0.50 & 60 & 56 & 36\end{array}$



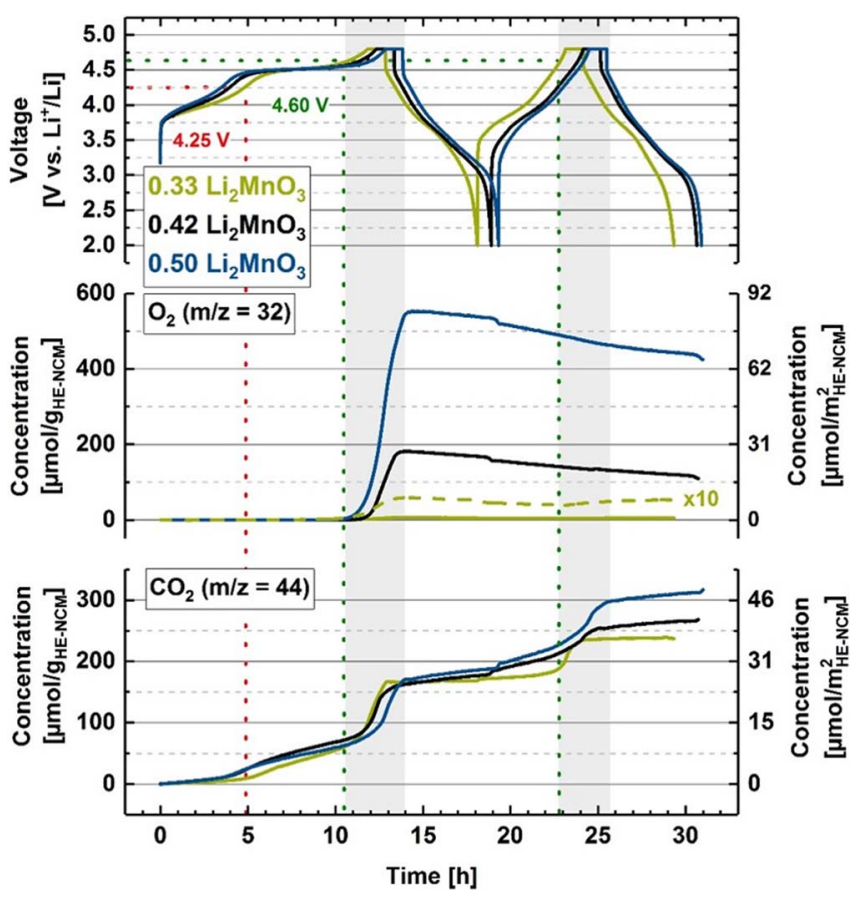

Figure 3. OEMS measurements for the first two charge/discharge cycles in a half-cell with three different HE-NCM compositions (see also Table I). Upper panel: charge/discharge voltage vs. time; middle/lower panel: evolution of the concentrations of concomitantly evolved $\mathrm{O}_{2} / \mathrm{CO}_{2}$ given in units of either $\mu \mathrm{mol} / \mathrm{g}_{\mathrm{AM}}$ (left axes) or $\mu \mathrm{mol} / \mathrm{m}^{2} \mathrm{AM}$ (right axes). Cells were charged at $\mathrm{C} / 10$ rate to $4.8 \mathrm{~V}$, followed by $1 \mathrm{~h} \mathrm{CV}$-step at $4.8 \mathrm{~V}$ and a consecutive discharge at $\mathrm{C} / 5$ to $2.0 \mathrm{~V}$ and another full charge/discharge cycle at $\mathrm{C} / 5$. Cells were composed of metallic Li counter electrode and a Celgard separator (CG2500) and experiments were conducted at $25^{\circ} \mathrm{C}$ in FEC:DEC (2:8 g:g) with $1 \mathrm{M} \mathrm{LiPF}_{6}$. The vertical dashed red line indicates the first onset of $\mathrm{CO}_{2}$ evolution, and the vertical dashed green lines mark the potential of $4.6 \mathrm{~V}$ where the onset of $\mathrm{O}_{2}$ evolution occurs.

material (even though for mechanistically different reasons, an irreversible capacity loss is also observed for NCM 111). ${ }^{41,42}$ However, for all compositions an offset between capacity loss during the first cycle and the cyclable lithium capacity in the graphite anodes of about $20-27 \mathrm{mAh} / \mathrm{g}$ is observed. This capacity offset must correspond to an irreversible loss of active lithium in side-reactions during the first charge/discharge cycle and cannot be assigned to typical anode SEI losses, as the SEI was already preformed on the graphite electrodes. The specific reactions leading to this phenomenon are unfortunately not clear at this time. However, Figure 2 shows that an increasing $\mathrm{Li}_{2} \mathrm{MnO}_{3}$ content leads to a higher amount of active lithium within a HE-NCM//Graphite full-cell. Thus, it is expected that this additional lithium can be utilized for SEI formation or stored in the graphite anode as lithium reservoir that can be utilized during cycling. Therefore, the full-cell performance is expected to be improved for higher $\mathrm{Li}_{2} \mathrm{MnO}_{3}$ which will be discussed later.

Oxygen release during activation.-To examine the effect of different $\mathrm{Li}_{2} \mathrm{MnO}_{3}$ onto the oxygen release of overlithiated NCM materials and to get insights if electrochemical $\mathrm{Li}_{2} \mathrm{MnO}_{3}$ activation accompanied by bulk oxygen release is feasible, results of the OEMS measurements on all three compositions are shown in Figure 3. The upper panel shows the galvanostatic charge/discharge profiles between 2.0 and $4.8 \mathrm{~V}$ against a Li counter electrode, and the middle/lower panels depict the concentration of the concomitantly evolved $\mathrm{O}_{2} / \mathrm{CO}_{2}$; concentrations are given in terms of both $\mu \mathrm{mol} / \mathrm{g}_{\mathrm{AM}}$ (left axis) and $\mu \mathrm{mol} / \mathrm{m}_{\mathrm{AM}}^{2}$ (right axis), whereby the latter surface normalized concentration will be used in the discussion section for comparison with the stochiometric NCM material. The first onset of $\mathrm{CO}_{2}$ evolution can be observed at $4.2 \mathrm{~V}$, followed by a rapid increase in $\mathrm{CO}_{2}$ upon the onset of oxygen release at $4.6 \mathrm{~V} \mathrm{vs}$. $\mathrm{Li}^{+} / \mathrm{Li}$, i.e., at the end of the first charge activation plateau. Quite striking when comparing the different HE-NCMs is that the amount of evolved $\mathrm{CO}_{2}$ is essentially identical for all materials, the extent of $\mathrm{O}_{2}$ release decreases substantially with decreasing $\mathrm{Li}_{2} \mathrm{MnO}_{3}$.

However, concerning the origin of $\mathrm{CO}_{2}$ from stochiometric and overlithiated layered oxides, there is an ongoing debate: while Luo et al. ${ }^{26}$ suggested that the main part of $\mathrm{CO}_{2}$ evolved from overlithiated oxides derives from electrolyte oxidation with lattice oxygen, it has been proposed by Renfrew et al. ${ }^{43}$ that $\mathrm{CO}_{2}$ evolution is exclusively triggered by the decomposition of $\mathrm{Li}_{2} \mathrm{CO}_{3}$ surface impurities. However, Jung et al. ${ }^{8,10,44}$ and Strehle et al. ${ }^{25}$ proposed another concept for stochiometric and overlithiated layered oxides, respectively, suggesting that $\mathrm{CO}_{2}$ evolution starting at $4.2 \mathrm{~V}$ vs. $\mathrm{Li}^{+} / \mathrm{Li}$ before the onset of oxygen release is produced by the oxidation of surface impurities, while the released oxygen is suggested to react with the carbonate electrolyte causing $\mathrm{CO}_{2}$ evolution, consistent with the concomitant rapid increase in $\mathrm{CO}_{2}$ concentration. While the exact mechanism leading to $\mathrm{CO}_{2}$ evolution is still subject to ongoing discussions, we will here adopt the mechanistic view proposed by Strehle et al. and Jung et al. As mentioned above, a rather striking observation is the $\approx 100$-fold variation in the amount of oxygen released by the end of the first activation charge for the different $\mathrm{Li}_{2} \mathrm{MnO}_{3}$ contents: $\approx 6 \mu \mathrm{mol} / \mathrm{g}$ $\left(\approx 1 \mu \mathrm{mol} / \mathrm{m}^{2}\right)$ for $0.33 \mathrm{Li}_{2} \mathrm{MnO}_{3}, \approx 180 \mu \mathrm{mol} / \mathrm{g}\left(\approx 28 \mu \mathrm{mol} / \mathrm{m}^{2}\right)$ for $0.42 \mathrm{Li}_{2} \mathrm{MnO}_{3}$, and $\approx 550 \mu \mathrm{mol} / \mathrm{g}\left(\approx 85 \mu \mathrm{mol} / \mathrm{m}^{2}\right)$ for $0.50 \mathrm{Li}_{2} \mathrm{MnO}_{3}$ content. If compared to the amount of $\mathrm{O}_{2}$ which would be expected for the historically proposed bulk activation of $\mathrm{Li}_{2} \mathrm{MnO}_{3}(1600 \mu \mathrm{mol} / \mathrm{g}$ for $0.33 \mathrm{Li}_{2} \mathrm{MnO}_{3}, 2000 \mu \mathrm{mol} / \mathrm{g}$ for $0.42 \mathrm{Li}_{2} \mathrm{MnO}_{3}$, and $2350 \mu \mathrm{mol} / \mathrm{g}$ for $0.50 \mathrm{Li}_{2} \mathrm{MnO}_{3}$ ), bulk oxygen release does not seem to be a feasible mechanism for these overlithiated materials. As already shown in a previous study, oxygen release caused by a chemical layer-tospinel transformation leading to the formation of a resistive surface layer and concomitant oxygen release from near-surface regions can explain the phenomena of oxygen release for $\mathrm{HE}_{-} \mathrm{NCMs}^{25}$ as well as for classical NCM materials. ${ }^{9,10}$ In these reports as well as in our present study, the main part of the oxygen evolution is detected during the first charge of the material, while rather small amounts of $\mathrm{O}_{2}$ evolution can be detected during the second cycle. The continuous oxygen consumption during the cycling procedure indicated by the decreasing $\mathrm{O}_{2}$ concentration after the first charging cycle (see middle panel in Figure 3) is ascribed to a gradual reduction of oxygen to $\mathrm{Li}_{2} \mathrm{O}_{2}$ on the lithium counter electrode, shown by Yabuuchi et al. to occur below $3.0 \mathrm{~V}$ vs. $\mathrm{Li}^{+} / \mathrm{Li}^{22}$ Furthermore, a more sudden oxygen consumption can be observed when the cathode is cycled below $3.0 \mathrm{~V}$ vs. $\mathrm{Li}^{+} / \mathrm{Li}$ (e.g., at $\approx 19 \mathrm{~h}$ in Figure 3 ), whereby the initially formed superoxide radical causes a sharp $\mathrm{CO}_{2}$ increase due to reaction with the electrolyte. ${ }^{22}$ During the first charging cycle, the onset of $\mathrm{O}_{2}$ evolution is accompanied by a rapid increase of the $\mathrm{CO}_{2}$ evolution rate, as discussed above. However, while no further evolution of $\mathrm{O}_{2}$ can be observed in the second cycle, further $\mathrm{CO}_{2}$ evolution can be detected at the potential where $\mathrm{O}_{2}$ started to evolve in the first cycle $(\approx 4.6 \mathrm{~V})$, indicating further oxygen release from the cathode material, even if no molecular $\mathrm{O}_{2}$ evolution can be detected anymore.

Galvanostatic cycling of half-cells.-As a next step, Figure 4 shows the half-cell cycling data for all three different compositions over 50 cycles at a rather slow rate of $\mathrm{C} / 5$ and with a high amount of electrolyte $(120 \mu \mathrm{l})$. Figure $4 \mathrm{a}$ depicts the discharge capacity retention for the materials, whereby the material with the highest $\mathrm{Li}_{2} \mathrm{MnO}_{3}$ content also shows the highest initial capacities, as expected from Table I and Figure 1. The capacity of the $0.50 \mathrm{Li}_{2} \mathrm{MnO}_{3}$ material (blue symbols) decreases strongly during the first 20 cycles, resulting in a capacity loss of $28 \mathrm{mAh} / \mathrm{g}$ between cycle 3 and cycle $50(253 \mathrm{mAh} / \mathrm{g}$ to $225 \mathrm{mAh} / \mathrm{g}$ ), while the capacity fading of the $0.42 \mathrm{Li}_{2} \mathrm{MnO}_{3}$ over the same cycles is much lower $(255 \mathrm{mAh} / \mathrm{g}$ to $240 \mathrm{mAh} / \mathrm{g})$, amounting to a capacity loss of $15 \mathrm{mAh} / \mathrm{g}$. The lowest capacity fading of roughly $7 \mathrm{mAh} / \mathrm{g}$ between cycle 3 and 50 is observed for the $0.33 \mathrm{Li}_{2} \mathrm{MnO}_{3}$ ( $247 \mathrm{mAh} / \mathrm{g}$ to $240 \mathrm{mAh} / \mathrm{g}$ ). Comparing this with the results from Figure 3 suggests that a higher oxygen release leads to more extensive 

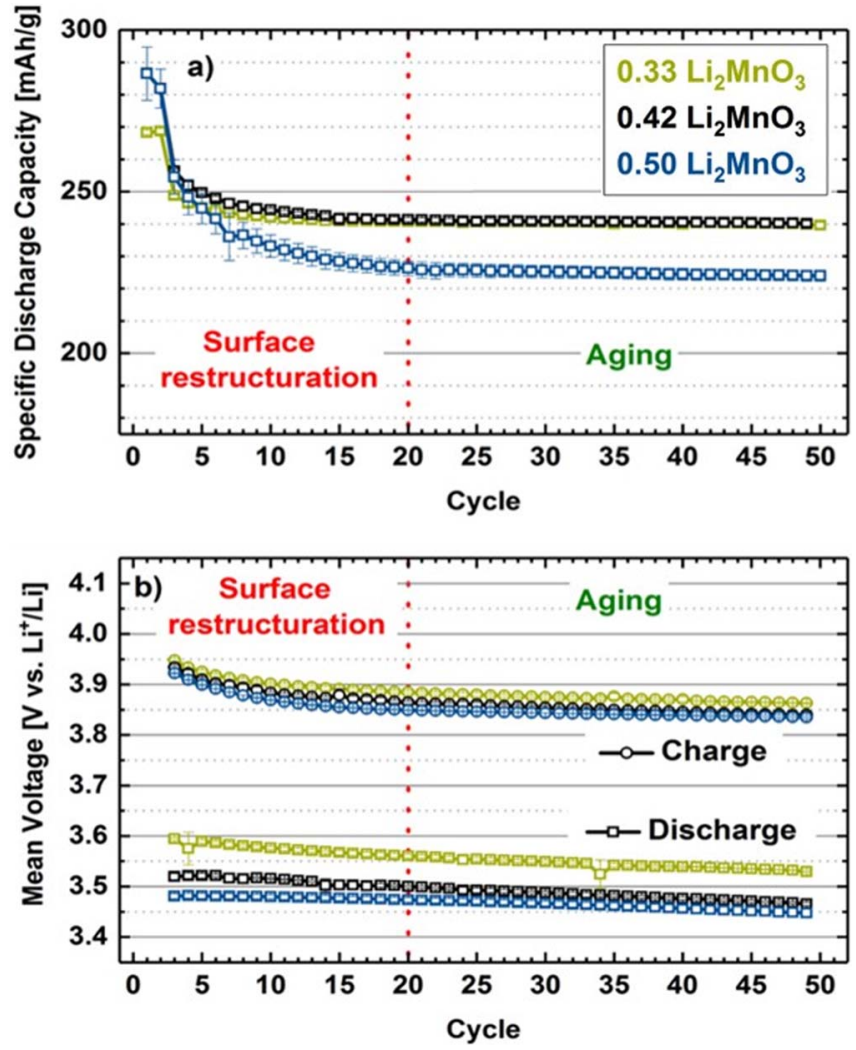

Figure 4. Electrochemical cycling at $\mathrm{C} / 5$ rate of the different HE-NCM compositions at $25^{\circ} \mathrm{C}$ using a $\mathrm{Li}$ counter electrode, FEC:DEC (2:8 g:g) with $1 \mathrm{M}$ $\mathrm{LiPF}_{6}$ electrolyte, and a glassfiber separator. The first activation cycle was carried out at $\mathrm{C} / 10$ to $4.8 \mathrm{~V}$ where the potential was held for $1 \mathrm{~h}$ and then the cell was discharged at $\mathrm{C} / 5$ to $2.0 \mathrm{~V}$, followed by an analogous second activation cycle at $\mathrm{C} / 5$ (up to $4.8 \mathrm{~V}+1 \mathrm{~h} \mathrm{CV}$ ); all further cycling (i.e., starting at the third cycle) was carried out at $\mathrm{C} / 5$ rate without any $\mathrm{CV}$-steps (CC charge/discharge) between $2.0 \mathrm{~V}$ and $4.7 \mathrm{~V}$. (a) shows the specific discharge capacity as a function of the cycle number (note that the first two discharge capacities are cycled up to $4.8 \mathrm{~V}$ followed by $1 \mathrm{~h} \mathrm{CV}$ ), while (b) shows the corresponding mean charge and discharge voltage (as defined by Eq. 1 in Jung et al. ${ }^{10}$ ). All data points represent the average of at least two independent measurements and the error bars reflect the maximum and minimum of the measured values.

surface degradation and a concomitant decrease of the electrochemical performance; the effect of oxygen release on active material loss will be discussed and quantified in the discussion section. As oxygen release is hypothesized to be correlated to the voltage hysteresis and the hysteresis between charge and discharge, ${ }^{11,45}$ one might pose the question whether the large differences in oxygen release shown in Figure 3 also have such a big influence onto the voltage fading of the different materials. The mean charge and discharge voltages are shown in Figure $4 \mathrm{~b}$. It can be seen that the mean charge voltage fading is comparable for all three materials, showing a fading of $\approx 90-100 \mathrm{mV}$ between cycle 3 and 50 for all materials. The same observation can be made for the mean discharge voltage fading, which does not differ largely between the different materials $(\approx 40-70 \mathrm{mV}$ ). Thus, while the $\mathrm{O}_{2}$ release increases by almost two orders of magnitude as the $\mathrm{Li}_{2} \mathrm{MnO}_{3}$ content is increased, the differences in voltage fading are rather minor, which suggests that the main cause of the voltage fading of HE-NCMs is not related directly to the oxygen release. Therefore, the oxygen release is a side reaction occurring at the HE-NCM nearsurface region, ${ }^{25}$ while reversible and irreversible transition metal migration in the bulk material cause the main voltage fading and the high hysteresis. ${ }^{35,45,46}$

Figure 5 depicts the dQ/dV plots for cycle 3, cycle 20, and cycle 48 extracted from the cycling data shown in Figure 4. Hereby, cycle 3 is the first $\mathrm{C} / 5$ cycle between $2.0 \mathrm{~V}$ and $4.7 \mathrm{~V}$ and therefore
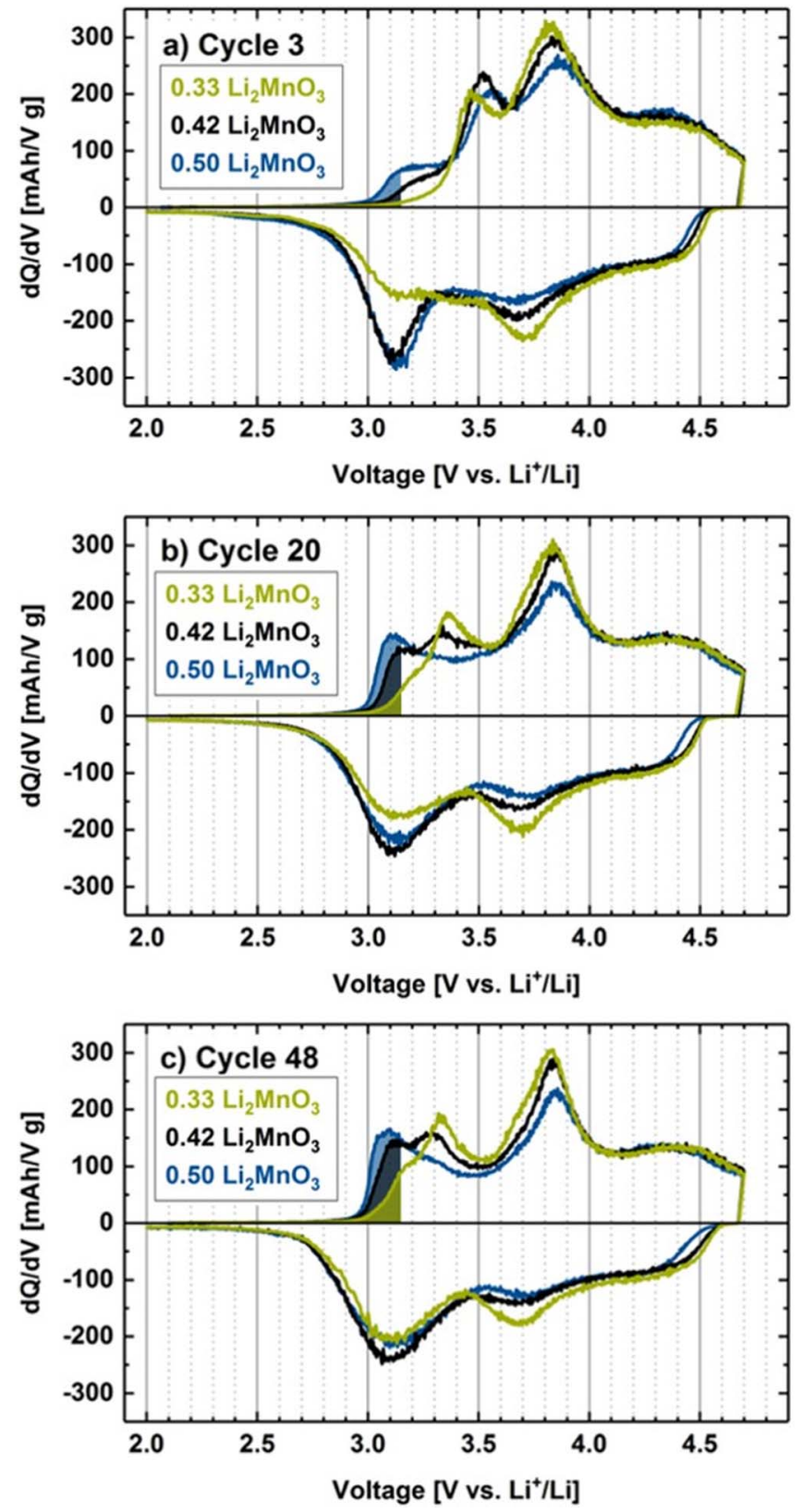

Figure 5. Electrochemical cycling of the different HE-NCM compositions at $25^{\circ} \mathrm{C}$ using a $\mathrm{Li}$ counter electrode, FEC:DEC $(2: 8 \mathrm{~g}: \mathrm{g})$ with $1 \mathrm{M} \mathrm{LiPF}_{6}$ electrolyte, and a glassfiber separator. The activation and cycling procedure is that same as that shown/described in Figure 4 . All dQ/dV plots were recorded at $\mathrm{C} / 5$ for cycle 3 (a), cycle 20 (b) and cycle 48 (c). The shaded areas in the charging cycles represent the hypothesized rocksalt-to-spinel transition.

is subjected to the same cycling conditions as cycle 20 and 48 . For the characterization of the mean voltages as well as the evolution of the spinel surface layer, we will focus on the charging curve of the materials, as the discharge shows very high impedances and limitations of Li diffusion within the bulk of the material, which is part of a separate study. ${ }^{14}$ The most striking differences can be observed by a peak in the $\mathrm{dQ} / \mathrm{dV}$ plot growing at roughly $3.1 \mathrm{~V}$ during the charge (shadowed areas in Figure 5). In Figure 5a and Figure 5b it can be seen that the area under this peak is largest for the 0.50 $\mathrm{Li}_{2} \mathrm{MnO}_{3}$ material that also has the highest $\mathrm{O}_{2}$ release, while for the material with the lowest oxygen release $\left(0.33 \mathrm{Li}_{2} \mathrm{MnO}_{3}\right)$ the area under this peak is lowest. Therefore, we suggest that this peak might be correlated to an oxygen deficient, spinel-like electrochemically active 

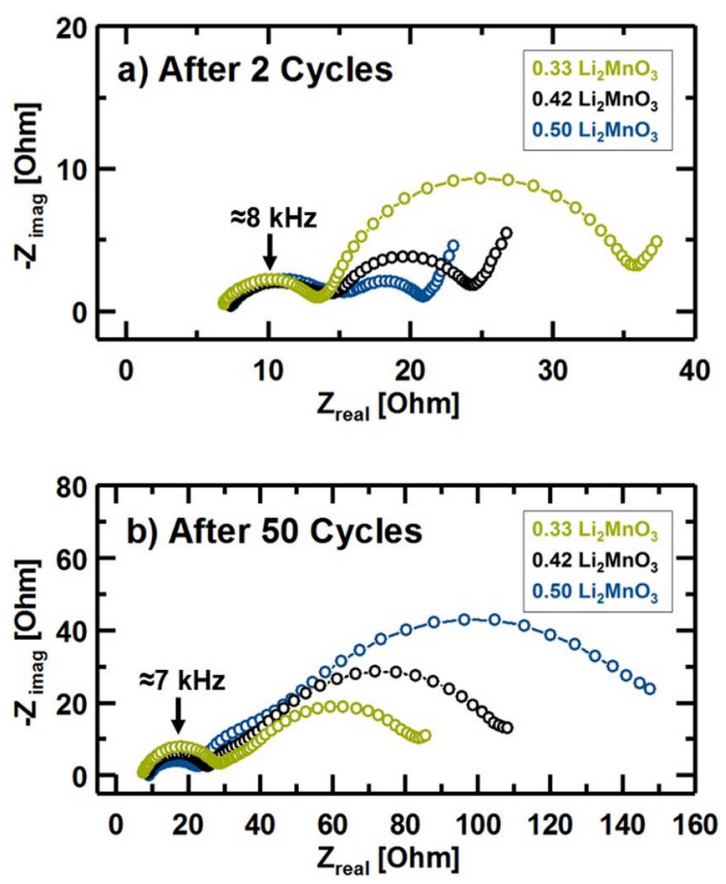

Figure 6. Impedance spectra measured in symmetric coin cells with cathodes harvested at 50\% SOC (a) after the two-cycle activation procedure and (b) after a total of 50 cycles according to the procedure shown in Figure 4. Symmetric cells were built with a $300 \mu \mathrm{m}$ glassfiber separator and with $95 \mu \mathrm{L}$ of $1 \mathrm{M} \mathrm{LiPF}_{6}$ in FEC:DEC (2:8 g:g) electrolyte. Impedance spectra were measured at the OCV at $50 \%$ SOC (between $300 \mathrm{kHz}$ and $30 \mathrm{mHz}$ with an amplitude of $10 \mathrm{mV}$ ).

surface structure, which would also be consistent with the observations by Bruce et al. and Thackeray, who proposed the rocksalt-to-spinel transition $\left(\mathrm{Li}_{2} \mathrm{Mn}_{2} \mathrm{O}_{4} \rightarrow \mathrm{LiMn}_{2} \mathrm{O}_{4}+\mathrm{Li}^{+}+\mathrm{e}^{-}\right)$at such potentials. ${ }^{47,48}$ Comparing the evolution of the area under these peaks, it can be clearly seen that it increases substantially from cycle 3 to cycle 20 , while it remains relatively constant between cycle 20 and cycle 48 . This behavior reflects the evolution of the capacity loss with cycling, which is most pronounced during the first 20 cycles, while afterwards the capacity stays approximately constant (Figure 4a). Thus, the capacitive contribution from the first charging peak in the $\mathrm{dQ} / \mathrm{dV}$ plot seems to correlate with the capacity loss, which we will further quantify in the discussion section, including the relationship of this feature with the extent of oxygen release.

Impedance spectroscopy in symmetric cells.-It has been reported in the literature that surface degradation of layered oxides, caused by oxygen release, can lead to spinel and rocksalt like structures at the surface of the cathode material, leading to drastic increases in the charge transfer resistance, which in turn might be the cause of the so-called rollover failure. ${ }^{10,49}$ Figure 6 shows impedance spectra measured in symmetric cells for HE-NCM electrodes with the three different compositions (a) after 2 activation cycles, and (b) after another 48 cycles (total of 50 cycles) according to the procedure in Figure 4. Impedance spectra were acquired at OCV following a charge to 50\% SOC (based on the preceding full charge-discharge cycle). All Nyquist plots show two distinct semi-circles, one at high frequencies that shows the same resistance for all the materials both at cycle 2 and 50 (increasing from $\approx 8$ to $\approx 20 \Omega$ ), and one at lower frequencies which differs significantly for the different compositions. Previous studies have shown that the semi-circle at high frequencies for cathode electrodes can be assigned to a contact resistance at the interface of the cathode electrode with the aluminum current collector, ${ }^{50,51}$ which can also be rationalized by considering the electrode capacitance corresponding to this first semi-circle:

$$
C=\frac{1}{R 2 \pi f_{\max }}
$$

where $\mathrm{C}$ is the capacitance, $\mathrm{R}$ is the diameter of the semi-circle (divided by two in this case of a symmetric cell), and $f_{\max }$ is the frequency corresponding to the apex of the first semi-circle. For the data shown in Figure $6 \mathrm{a}$, the resistance for one electrode is $\mathrm{R} \approx 8 \Omega$ and $\mathrm{f}_{\max } \approx 8 \mathrm{kHz}$, equating to an electrode capacitance of $\approx 5 \mu \mathrm{F}$, which is similar for all HE-NCM compositions. To understand its origin, one may normalize it by either the surface area of the current collector $\left(\approx 1.5 \mathrm{~cm}^{2}\right.$ for the $14 \mathrm{~mm}$ diameter electrodes) or by the total surface area of the cathode electrode $\left(\approx 730 \mathrm{~cm}^{2}\right.$, based on the mass of HE$\mathrm{NCM}$ and conductive carbons in the electrode multiplied by their BET surface area), yielding either $\approx 3.2 \mu \mathrm{F} / \mathrm{cm}^{2}$ or $\approx 0.007 \mu \mathrm{F} / \mathrm{cm}^{2}$, respectively. If compared to the typical double layer capacitance which is on the order of $\approx 10^{1} \mu \mathrm{F} / \mathrm{cm}^{2}$, it is clear that the first semi-circle occurs due to a contact resistance at the interface between the electrode and the current collector. Detailed studies onto the origin of those contact resistances are reported elsewhere. ${ }^{50,51}$

The second semi-circle at lower frequencies can then be assigned to a charge-transfer resistance $\left(\mathrm{R}_{\mathrm{CT}}\right)$, which clearly differs largely for the different HE-NCM materials. First examining their impedance directly after the two activation cycles (Figure 6a), it can be seen that $\mathrm{R}_{\mathrm{CT}}$ decreases with increasing $\mathrm{Li}_{2} \mathrm{MnO}_{3}$ content and thus with increasing oxygen release (Figure 3 ). This could be rationalized by assuming either that the oxygen vacancies in the surface layer largely increase the lithium ion mobility and/or that the surface restructuration increases the porosity at the surface of the cathode material, concomitant with an increase in interfacial surface area and thus a lowering of the apparent charge transfer resistance.

Interestingly, the above discussed trend of a decreasing charge transfer resistance with increasing $\mathrm{Li}_{2} \mathrm{MnO}_{3}$ content reverses over the course of cycling (Figure 6b). Even though the resistance represented by the second semi-circle increases for all HE-NCMs from cycle 2 to cycle 50 (Figure 6b), it increases by a much larger factor for the $0.50 \mathrm{Li}_{2} \mathrm{MnO}_{3}$ ( $\approx 15$-fold) compared to the $0.33 \mathrm{Li}_{2} \mathrm{MnO}_{3}$ material $\left(\approx 2.5\right.$-fold), so that after 50 cycles the $0.50 \mathrm{Li}_{2} \mathrm{MnO}_{3}$ material now shows the highest impedance and therefore also the highest impedance buildup. As the thickness of the oxygen-deficient phase after the activation is expected to increase with the extent of $\mathrm{O}_{2}$ release and thus with the extent of overlithiation, the gradual transformation of this surface layer from perhaps an initially highly conductive disordered layered structure into a more resistive ordered spinel or rocksalt structure could explain the increase in the cycling induced impedance buildup with the extent of overlithiation. This hypothesis will be examined in the following by HRTEM analysis of pristine and cycled HE-NCMs.

High-resolution TEM measurements.-Figure 7 shows representative HRTEM images of the near-surface region for the material with an intermediate extent of overlithiation $\left(0.42 \mathrm{Li}_{2} \mathrm{MnO}_{3}\right)$ for the pristine material (a), after 2 cycles (b), and after 50 charge-discharge cycles (c), following the same cycling protocol as that shown/described in Figure 4. For the pristine material, a layered structure without any crystalline surface layer but with a thin amorphous surface layer can be seen, which we ascribe to carbonate and hydroxide surface impurities. The HRTEM image taken after 2 charge/discharge cycles (Figure $7 b$ ), i.e., after most of the oxygen has been released from the active material, clearly still shows a layered surface structure for which, however, a slight loss of density in the near-surface regions can be observed. This provides first hints that the release of oxygen initiates changes in the surface structure. After 50 charge/discharge cycles, Figure $7 \mathrm{c}$ clearly shows the presence of a pronounced surface layer with a thickness of roughly $4 \mathrm{~nm}$, whereby the corresponding FFT image in Figure $7 \mathrm{~d}$ indicates strong cation mixing within the spinel-type surface layer. These findings are consistent with the HRTEM analysis by Genevois et al. ${ }^{29}$ on chemically delithiated HE-NCM, indicating a strong surface restructuration after several charge/discharge cycles. 


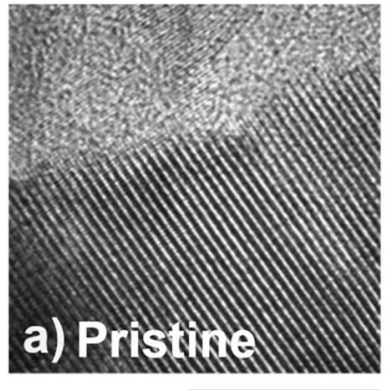

$10 \mathrm{~nm}$

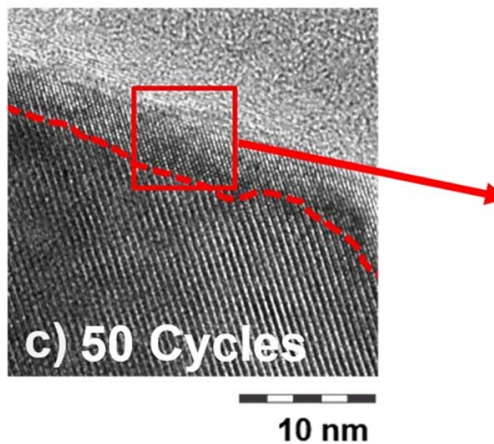

Figure 7. HRTEM analysis of the near-surface region of the $0.42 \mathrm{Li}_{2} \mathrm{MnO}_{3}$ HE-NCM material (a) in its pristine state, (b) after 2 cycles, and (c) after 50 cycles (the cycling procedure is according to that described in Figure 4). (d) shows the corresponding FFT image for the material after 50 cycles, taken in the red marked region in (c).

Furthermore, the here presented HRTEM measurements support one of our above assumptions used to interpret the EIS measurements shown in Figure 6, namely the initial formation of surface layer with reduced density after activation and the associated $\mathrm{O}_{2}$ release, followed by a densification ${ }^{28}$ and spinel-type surface layer formation upon extended charge/discharge cycling.

HRTEM images for all HE-NCM compositions were also collected after 50 cycles. The $0.33 \mathrm{Li}_{2} \mathrm{MnO}_{3}$ material is shown in Figures $8 \mathrm{a}-$ $8 \mathrm{c}$. Figure $8 \mathrm{a}$ shows an entire primary particle, displaying a perfectly layered bulk material as demonstrated by the FFT image (Figure 8b), with a surface-layer in the range of 1-2 nm. The latter is marked by the red dashed line and magnified in Figure 8c; unfortunately, this layer was too thin to take an FFT image. The HRTEM image of an entire primary particle of the $0.42 \mathrm{Li}_{2} \mathrm{MnO}_{3}$ material is shown in Figure 8d, which also is a well-ordered layered bulk material, as demonstrated by the FFT image taken from the center of the particle (Figure 8f). However, the restructuration of the surface is much more pronounced for this material, showing a surface layer thickness in the range of $4 \mathrm{~nm}$ and even thicker in some areas (marked by the red dashed line in Figure 8d). The FFT image from the surface layer (Figure 8e) is in line with the image shown in Figure 7d, showing strong cation mixing in a spinel-type surface layer. Finally, the HRTEM images for the $0.50 \mathrm{Li}_{2} \mathrm{MnO}_{3}$ material are shown in Figures $8 \mathrm{~g}-8 \mathrm{i}$. In these images it can be observed that the formation of a spinel-type structure is now not only limited to the surface, but also alters the bulk material. The FFT image in Figure 8h from one area within the particle indicates an intact layered structure, while Figure $8 \mathrm{i}$ from a different region within the same particle already shows cation mixing within the bulk material and changes of the layered structure. In summary, all these observations present strong evidence that the higher oxygen release during activation produced by higher degrees of overlithiation leads to an increasingly pronounced growth of surface layers, initially formed as reduced density layered structures and transformed upon cycling into spinel-type phases with strong cation mixing.
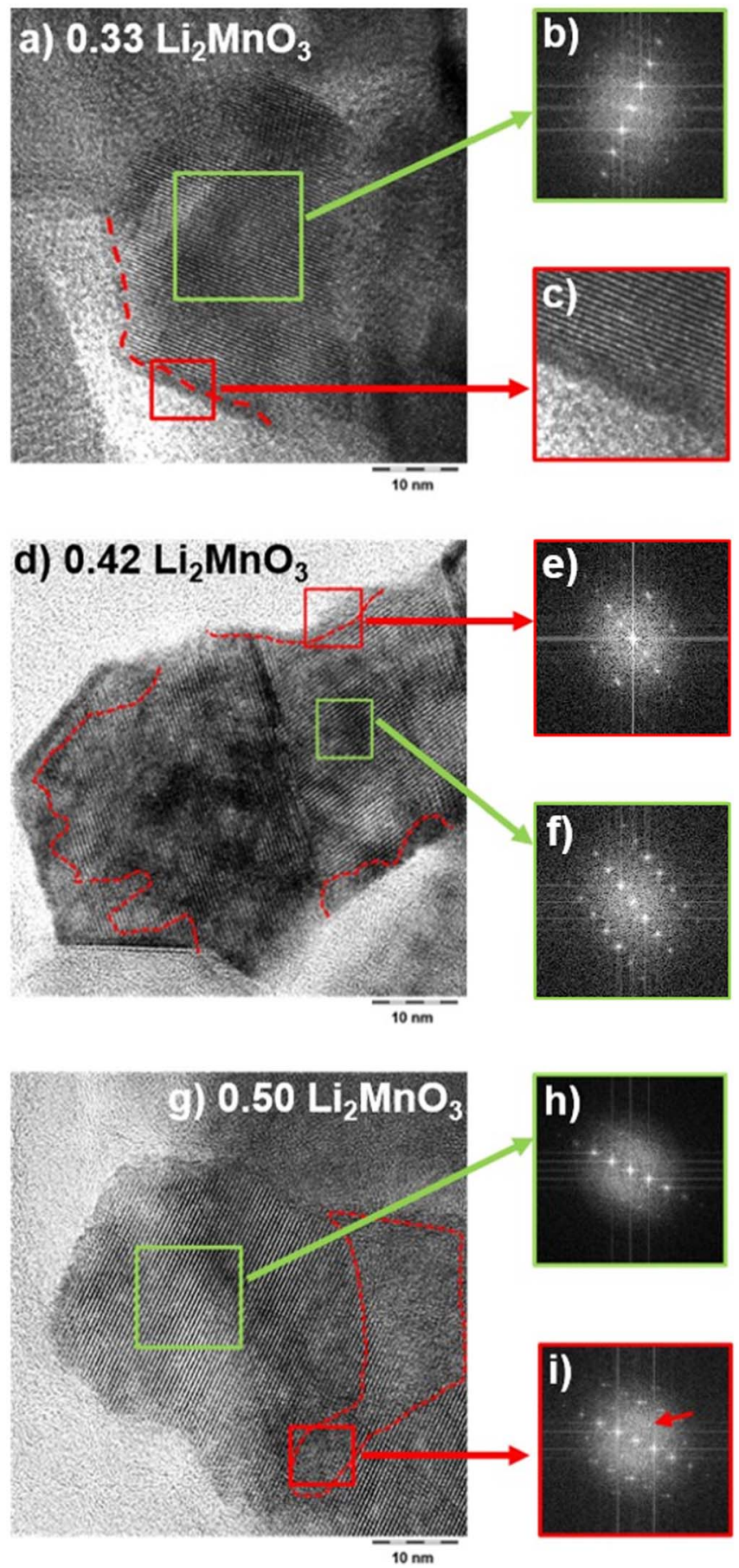

Figure 8. HRTEM images showing particle degradation for HE-NCMs with (a, c) $0.33 \mathrm{Li}_{2} \mathrm{MnO}_{3}$, (d) $0.42 \mathrm{Li}_{2} \mathrm{MnO}_{3}$, and (g) $0.50 \mathrm{Li}_{2} \mathrm{MnO}_{3}$ content. Corresponding FFT images after 50 cycles from the marked regions in the HR-TEM images are shown: (b) for the bulk of the $0.33 \mathrm{Li}_{2} \mathrm{MnO}_{3}$ material; (e) and (f) for the surface and bulk, respectively, of the $0.42 \mathrm{Li}_{2} \mathrm{MnO}_{3}$ material; (h) and (i) for the bulk and surface, respectively, of the $0.50 \mathrm{Li}_{2} \mathrm{MnO}_{3}$ material.

\section{Discussion}

Estimation of spinel-type surface layer thickness.-Strehle et al. have recently shown that the oxygen evolution in Li- and Mn-rich layered oxides occurs $i$ ) right after the activation plateau and ii) also continues during the $\mathrm{OCV}$ at $4.8 \mathrm{~V}$. Based on these results it was proposed that oxygen release from the bulk material seems to be unlikely, which led to the conclusion that high voltage charging and high degrees of delithiation destabilize the material's surface and ultimately 
Table III. $\mathrm{Li}_{2} \mathrm{MnO}_{3}$ content, molar mass and theoretically required oxygen release for a $100 \%$ conversion into a spinel structure for HE-NCMs delithiated at $4.6 \mathrm{~V}\left(\mathrm{n}\left(\mathrm{O}_{2}^{\text {theo }}\right)\right.$, see Equation 8), ${ }^{10,25}$ calculated acc. to Equations 4-8.

$\mathrm{Li}_{2} \mathrm{MnO}_{3}$ content Molar mass $[\mathrm{g} / \mathrm{mol}] \quad 100 \% \mathrm{O}_{2}$ conversion $[\mu \mathrm{mol} / \mathrm{g}]$

$\begin{array}{lll}0.33 & 88.4 & 2941 \\ 0.42 & 86.8 & 2880 \\ 0.50 & 85.2 & 3521\end{array}$

result in a surface restructuration of the material. ${ }^{25}$ Similar behavior was also shown to occur for stochiometric NCM materials, leading to a chemically driven formation of a spinel and/or rocksalt surface layer upon delithiation. ${ }^{10}$ Such chemically driven spinel and/or rocksalt formation have been shown and intensively characterized for the thermally induced transformation of partially delithiated NCMs. ${ }^{52,53}$ The general chemical reaction for spinel formation is given in Equation 3. Since rocksalt structures could not be observed by HRTEM measurements (see Figure 7 and Figure 8), the surface layer thickness is estimated only assuming the formation of a spinel surface layer. ${ }^{10,25}$

$$
\mathrm{Li}_{\mathrm{x}} \mathrm{Me}_{\mathrm{y}} \mathrm{O}_{2} \rightarrow \frac{\mathrm{x}+\mathrm{y}}{3} \mathrm{Li}_{3-\frac{3 \mathrm{y}}{(\mathrm{x}+\mathrm{y})}} \mathrm{Me}_{\frac{3 \mathrm{y}}{(\mathrm{x}+\mathrm{y})}} \mathrm{O}_{4}+\frac{3-2(\mathrm{x}+\mathrm{y})}{3} \mathrm{O}_{2} \uparrow
$$

As starting compound for the spinel formation according to Equation 3 , it is assumed that material restructuration starts at the oxygen onset potential, so the starting compound for the material restructuration is the partially delithiated phase at $4.6 \mathrm{~V}$ during the first charge, as already suggested by Strehle et al. ${ }^{25}$ Thus, the amount of lithium that remains in the structure at the oxygen onset (x-value in Eq. 3) needs to be estimated using Equation 4

$$
\Delta \mathrm{x}_{\mathrm{Li}}=\frac{\mathrm{QM}}{\mathrm{F}}
$$

with Q being the capacity reached at the oxygen onset during the first charge (from Figure 3), M being the molar mass of the pristine HE-NCM, and F being the Faraday constant. With these calculations, residual lithium contents of $\mathrm{Li}_{0.25}\left(0.33 \mathrm{Li}_{2} \mathrm{MnO}_{3}\right), \mathrm{Li}_{0.29}(0.42$ $\left.\mathrm{Li}_{2} \mathrm{MnO}_{3}\right)$, and $\mathrm{Li}_{0.25}\left(0.50 \mathrm{Li}_{2} \mathrm{MnO}_{3}\right)$ are found and can be further replaced into the general equations for spinel formation (Equations 3 ). The resulting transformations into the spinel phase for the different materials are shown in Equations 5 to 7.

Spinel formation for the $0.33 \mathrm{Li}_{2} \mathrm{MnO}_{3}$ material delithiated to 4.6 V:

$$
\mathrm{Li}_{0.25} \mathrm{Me}_{0.86} \mathrm{O}_{2} \rightarrow 0.37 \mathrm{Li}_{0.68} \mathrm{Me}_{2.32} \mathrm{O}_{4}+0.26 \mathrm{O}_{2} \uparrow
$$

Spinel formation for the $0.42 \mathrm{Li}_{2} \mathrm{MnO}_{3}$ material delithiated to 4.6 V:

$$
\mathrm{Li}_{0.29} \mathrm{Me}_{0.83} \mathrm{O}_{2} \rightarrow 0.37 \mathrm{Li}_{0.78} \mathrm{Me}_{2.22} \mathrm{O}_{4}+0.25 \mathrm{O}_{2} \uparrow
$$
4.6 V:

Spinel formation for the $0.50 \mathrm{Li}_{2} \mathrm{MnO}_{3}$ material delithiated to

$$
\mathrm{Li}_{0.25} \mathrm{Me}_{0.80} \mathrm{O}_{2} \rightarrow 0.35 \mathrm{Li}_{0.71} \mathrm{Me}_{2.29} \mathrm{O}_{4}+0.30 \mathrm{O}_{2} \uparrow
$$

These equations give the theoretical loss of oxygen per mole of HENCM for a $100 \%$ layered-to-spinel conversion $\left(\mathrm{O}_{2}^{\text {theo }}\right)$, from which the moles of oxygen released for a $100 \%$ conversion of the entire particle into the spinel $\left(\mathrm{n}\left(\mathrm{O}_{2}^{\text {theo }}\right)\right)$ can be easily calculated according to formula 8, using the molar mass of the different HE-NCM compositions. Table III shows the molar mass values for the different compositions, as well as the theoretical oxygen release which would be required for a $100 \%$ of spinel formation calculated from the equations above.

$$
\mathrm{n}\left(\mathrm{O}_{2}^{\text {theo }}\right)=\frac{\mathrm{O}_{2}^{\text {theo }}}{\mathrm{M}}
$$

The ratio of oxygen release expected for a $100 \%$ phase transformation $\left(\mathrm{n}\left(\mathrm{O}_{2}^{\text {theo }}\right)\right)$ into a spinel structure and the actual oxygen evolution measured by OEMS $\left(\mathrm{n}\left(\mathrm{O}_{2}^{\text {meas }}\right)\right)$ can be used to calculate the molar fraction of layered material converted into a spinel-type structure.

$$
\mathrm{x}_{\text {surface layer }}=\frac{\mathrm{n}\left(\mathrm{O}_{2}^{\text {meas }}\right)}{\mathrm{n}\left(\mathrm{O}_{2}^{\text {theo }}\right)}
$$

To translate the molar fraction into a surface layer thickness, the approximate particle radius is estimated from the BET areas $\left(\mathrm{A}_{\mathrm{BET}}\right)$ given in Table I according to Equations 10 , with $\rho_{\mathrm{HE}-\mathrm{NCM}}$ being the crystallographic density of the pristine material $\left(\rho_{\mathrm{HE}-\mathrm{NCM}}=4.2 \mathrm{~g} / \mathrm{cm}^{3}\right)$.

$$
r=\frac{3}{A_{\mathrm{BET}} \rho_{\mathrm{HE}-\mathrm{NCM}}}
$$

From the radius and the molar fraction of the spinel phase, the surface layer thickness can be easily assumed using Equations 11 and 12. More detailed information regarding these calculations have been reported by Strehle et al. and Jung et al. ${ }^{10,25}$

$$
\begin{gathered}
r^{\prime}=r\left(1-x_{\text {surface layer }}\right)^{1 / 3} \\
t_{\text {surface layer }}=r-r^{\prime}
\end{gathered}
$$

Based on the equations and assumptions discussed above, all results from the OEMS measurements and the results of the above calculations are summarized in Table IV. For the gas quantification two different models are taken into account: Model I is based on the amount of $\mathrm{O}_{2}$ and $\mathrm{CO}_{2}$ released above $4.6 \mathrm{~V}$ during the first charge, while Model II is based on the amount of $\mathrm{O}_{2}$ and $\mathrm{CO}_{2}$ released above 4.6 $\mathrm{V}$ during the first and the second charge, whereby the evolved amount of gases are taken from Figure 3 (from the gray shaded regions). As mentioned before, the assumption that the $\mathrm{CO}_{2}$ evolved at high potentials is formed by lattice oxygen from the cathode material is still subject of ongoing discussions, ${ }^{10,26,43}$ but recent measurements with ${ }^{13} \mathrm{C}$ labeled EC are in support of this. ${ }^{44}$ Furthermore, the amount of evolved $\mathrm{CO}$ was not considered, as it is negligible with the here used FEC-based electrolytes (data not shown).

From Table IV it can be seen that the oxygen evolution strongly depends on the material composition and is nearly 100-times higher for the $0.50 \mathrm{Li}_{2} \mathrm{MnO}_{3}$ compared to the $0.33 \mathrm{Li}_{2} \mathrm{MnO}_{3}$ material. This is consistent with the increase of the surface (and bulk) restructuration with increasing lithium content observed in the HRTEM analysis (see Figure 8). In contrast, it is surprising that the amount of evolved $\mathrm{CO}_{2}$ is essentially independent of the HE-NCM composition and the amount of evolved oxygen, suggesting that the reaction between electrolyte and lattice oxygen saturates at a high level of oxygen release from HENCM. Furthermore, since the $\mathrm{CO}_{2}$ evolution at high potentials during the second charge is also likely due to the reaction of electrolyte with lattice oxygen (more apparent in the OEMS study by Jung et al. on NCMs $),{ }^{10}$ Model II is assumed to be the more representative scenario.

From the total amount of $\mathrm{CO}_{2}$ and $\mathrm{O}_{2}$ evolved at $\geq 4.6 \mathrm{~V}$, which we believe are reaction products of the electrolyte with lattice oxygen, the molar fraction of the resulting spinel surface layer as well as its thickness can be estimated; these are given for the different materials in Table IV. For the $0.33 \mathrm{Li}_{2} \mathrm{MnO}_{3}$ material, a roughly $2 \mathrm{~nm}$ thick surface layer could be detected by HRTEM, which is consistent with the spinel layer thickness calculated for Model II (see Table IV). A similarly good quantitative agreement is found for the $0.42 \mathrm{Li}_{2} \mathrm{MnO}_{3}$ material, with HRTEM images showing surface layers of roughly $4 \mathrm{~nm}$, the same as the thickness predicted by Model II. However, for the $0.50 \mathrm{Li}_{2} \mathrm{MnO}_{3}$ material the simple surface layer model fails, as oxygen depletion proceeds into the bulk of the material, leading to large domains of bulk degradation (see Figures $8 \mathrm{~g}-8 \mathrm{i}$ ). Nevertheless, when comparing semi-quantitatively the HRTEM images of the 0.50 $\mathrm{Li}_{2} \mathrm{MnO}_{3}$ material after 50 cycles, the molar fraction of $\approx 20 \mathrm{~mol} \%$ of spinel based on the gas evolution data (Table IV) seems to be a realistic value. Please note that the results discussed above and shown in Table IV suggest the formation of a $\mathrm{M}_{3}^{\prime} \mathrm{O}_{4}\left(\mathrm{M}^{\prime}=\mathrm{Li}+\mathrm{Me}\right)$ type spinel, as discussed in previous publications. ${ }^{10,25}$ Another possible spinel structure formed upon oxygen release might be a $\mathrm{LiMn}_{2} \mathrm{O}_{4}$ type spinel layer, which would lead to a lower oxygen loss per mole 
Table IV. Amounts of $\mathrm{O}_{2}$ and $\mathrm{CO}_{2}$ evolved at $\geq 4.6 \mathrm{~V}$ in the $1^{\text {st }}$ (Model I) as well as in the $1^{\text {st }}+2^{\text {nd }}$ cycle (Model II) from HE-NCMs with different $\mathrm{Li}_{2} \mathrm{MnO}_{3}$ contents (from the OEMS data in Figure 3). The molar fraction of the spinel surface layer $\left(x_{\text {surf. layer }}\right.$ ) is calculated from the sum of $\mathrm{O}_{2}$ and $\mathrm{CO}_{2}$ detected at $\geq 4.6 \mathrm{~V}$ according to the chemical reactions given in Equations 3-9 and the surface layer thickness $\left(t_{\text {surf. layer }}\right)$ is calculated from Equations 10-12.

Gas evolution ( $\geq 4.6 \mathrm{~V})\left[\mu \mathrm{mol} / \mathrm{g}_{\mathrm{AM}}\right]$

\begin{tabular}{|c|c|c|c|c|c|c|}
\hline $\mathrm{Li}_{2} \mathrm{MnO}_{3}$ content & Model & Total & $\mathrm{O}_{2}$ & $\mathrm{CO}_{2}$ & $\mathrm{x}_{\text {surf. layer }}[\mathrm{mol} \%]$ & $\mathrm{t}_{\text {surf. layer }}[\mathrm{nm}]$ \\
\hline \multirow[t]{2}{*}{0.33} & I & 96 & 6 & 90 & 3.3 & 1.2 \\
\hline & II & 146 & 6 & 140 & 5.0 & 1.9 \\
\hline \multirow[t]{2}{*}{0.42} & I & 265 & 180 & 85 & 9.2 & 3.5 \\
\hline & II & 305 & 180 & 125 & 11 & 4.0 \\
\hline \multirow[t]{2}{*}{0.50} & I & 650 & 550 & 100 & 19 & 7.3 \\
\hline & II & 695 & 550 & 145 & 20 & 7.8 \\
\hline
\end{tabular}

of converted HE-NCM, so that for the same amount of oxygen release a thicker spinel-type surface layer would be expected, based on the following general equation:

$$
\mathrm{Li}_{\mathrm{x}} \mathrm{Me}_{\mathrm{y}} \mathrm{O}_{2} \rightarrow \frac{\mathrm{y}}{2} \mathrm{Li}_{\frac{\mathrm{y}}{\mathrm{y}}} \mathrm{Me}_{2} \mathrm{O}_{4}+(1-\mathrm{y}) \mathrm{O}_{2} \uparrow
$$

Conducting the same calculations (Model II in Table IV), as shown in Equation 5-12, for the formation of $\mathrm{LiMn}_{2} \mathrm{O}_{4}$ type spinel layer, the following amounts of spinel ( $\mathrm{x}_{\text {surf. layer }}$ in $\mathrm{mol} \%$ ) will be obtained for the different materials: $9.2 \mathrm{~mol} \%\left(0.33 \mathrm{Li}_{2} \mathrm{MnO}_{3}\right), 16.5 \mathrm{~mol} \%(0.42$ $\left.\mathrm{Li}_{2} \mathrm{MnO}_{3}\right)$ and $29.6 \mathrm{~mol} \%\left(0.50 \mathrm{Li}_{2} \mathrm{MnO}_{3}\right)$, ending up with surface layers $\left(\mathrm{t}_{\text {surf. layer }}\right.$ in $\left.\mathrm{nm}\right)$ from $3.5 \mathrm{~nm}\left(0.33 \mathrm{Li}_{2} \mathrm{MnO}_{3}\right)$ to $6.4 \mathrm{~nm}(0.42$ $\mathrm{Li}_{2} \mathrm{MnO}_{3}$ ) up to $12 \mathrm{~nm}$ for the $0.50 \mathrm{Li}_{2} \mathrm{MnO}_{3} \mathrm{HE}-\mathrm{NCM}$. Comparing these values to the calculations for the $\mathrm{M}_{3} \mathrm{O}_{4}$ spinel layer, with predicted spinel fractions and thicknesses ranging from 5-20 mol.\% and from 1.9-7.8 nm, respectively (see Model II, Table IV), one can see that the formation of a $\mathrm{LiMn}_{2} \mathrm{O}_{4}$ type spinel would result in a $\sim 1.5$ fold larger estimated for the amount and the thickness of the spinel surface layer. Therefore, one should keep in mind that the here projected surface spinel layer amounts/thicknesses do depend on the actual phase that is formed after the oxygen release and as such are just rough estimates. However, taking into regard that the spinel forms due to cation migration at room temperature, we rather expect a disordered spinel with the stoichiometry $\mathrm{M}_{3} \mathrm{O}_{4}$ than a well ordered $\mathrm{LiMe}_{2} \mathrm{O}_{4}$ phase, as obtained from high temperature synthesis.

In summary, by correlating HRTEM images/analysis with the OEMS experiments we have proven that the oxygen release during the HE-NCM activation cycles is accompanied by the formation of a surface spinel-like layer and is not due to a bulk restructuration, as suggested in earlier reports. ${ }^{25,27-29}$ However, using a material with a very high lithium content, like the $0.50 \mathrm{Li}_{2} \mathrm{MnO}_{3}$ material in this study, a partial bulk transformation can be observed, amounting to $\approx 20 \mathrm{~mol} \%$ of the material being converted into a spinel-like phase (calculated from the oxygen evolution, shown in Model II from Table IV). While the TEM data are statistically not sufficient to provide exact quantitative surface layer thickness values for averaged over the entire material, they fit well to the quantification from the OEMS results. The partial bulk conversion for highly overlithiated HE-NCMs $(\approx 20 \mathrm{~mol} \%)$ now also explains previous studies from which it was concluded that the activation of HE-NCMs leads to a bulk transformation to a spinel-like phase. ${ }^{19,20,22,54}$ For example Yabuuchi et al. and Mohanty et al. have suggested bulk structural changes during the first charge due to oxygen removal from the bulk of the material based on $\mathrm{X}$-ray diffraction studies, both conducted with overlithiated HE-NCM with $0.50 \mathrm{Li}_{2} \mathrm{MnO}_{3}$ content ${ }^{22,54}$ Clearly, the results of structural, nonspatially resolved measurements are strongly dependent on the extent of overlithiation and perhaps on the synthesis of HE-NCM materials, which is the reason for the different mechanistic hypotheses which can be found in the literature. However, recent approaches using spatially resolved techniques ${ }^{38}$ lead to the same conclusions as presented in our study.

Evolution of the surface layer during cycling.-Now we want to discuss the evolution of the structural transformation during cy- cling, considering the OEMS measurements (Figure 3), the impedance spectroscopy analysis (Figure 6), and the HRTEM data (Figure 7 and Figure 8). The OEMS experiments show the first $\mathrm{CO}_{2}$ onset at $4.2 \mathrm{~V}$, which we believe is correlated to the oxidation of surface contaminants at potentials as low as $4.2 \mathrm{~V},{ }^{25,44}$ i.e., at a potentials far below the observed onset of oxygen evolution. At a potential of $\geq 4.6 \mathrm{~V}$, strong oxygen release occurs during the first charge cycle, accompanied by a striking increase in $\mathrm{CO}_{2}$ evolution, whereby it was shown that oxygen from the lattice is released as molecular oxygen and, at least partially as singlet oxygen, ${ }^{55}$ leading to $\mathrm{CO}_{2}$ formation from the reaction of reactive oxygen (surface) species with the electrolyte. ${ }^{10,26,55}$ While only traces of oxygen were detected by OEMS during the second charge cycle, a boost in $\mathrm{CO}_{2}$ evolution at $\geq 4.6 \mathrm{~V}$ (where the onset of oxygen evolution is observed in the first cycle) still suggests further reaction with lattice oxygen.

In contradiction to the OEMS analysis, which shows substantial $\mathrm{O}_{2}$ and $\mathrm{CO}_{2}$ evolution at $\geq 4.6 \mathrm{~V}$ in the first two cycles, HRTEM investigations of the $0.42 \mathrm{Li}_{2} \mathrm{MnO}_{3}$ material (Figure 7) do not show any structural changes at the surface of the material after 2 cycles, implying that although the main part of the oxygen is released, the layered structure is still preserved. However, a clear structural surface transformation into a spinel-like layer can be observed after 50 consecutive charge/discharge cycles for all HE-NCM compositions, the thickness of which correlates nicely with the gas evolution in the first two cycles (see above). Another key observation is that the impedance spectra in Figure 6 are consistent with the HRTEM measurements: i) after 2 cycles, the HE-NCMs with the highest oxygen release showed the lowest charge-transfer resistance (Figure 6a), which we associate with the formation of a layered surface structure with abundant vacancies caused by the high oxygen release, allowing for fast lithium diffusion; and, ii) the impedance spectra after 50 cycles showed the highest charge-transfer resistance for the material with the highest oxygen release (Figure 6b), suggesting that the initial oxygen-vacant layered surface structure underwent a structural transformation into a spinel-like phase, inhibiting lithium diffusion, particularly for the thicker layers formed at the more lithiumrich HE-NCMs. From these observations emerges the hypothesis that the release of lattice oxygen does not immediately induce a phase transformation of the formed oxygen-depleted surface layer. Instead, the above presented data suggest that only the de-lithiation/lithiation processes over the course of subsequent cycling leads to a progressive phase transformation of the layered oxygen-vacant surface region. The half-cell cycling data from Figure 4 provide strong evidence that this phase transformation process indeed takes place during the first 20 cycles, leading to the observed capacity loss due to the gradual transformation of the layered oxygen-vacant surface region into a spinel-like surface layer. This hypothesis is schematically depicted in Scheme 1.

Correlation between capacity fading and spinel surface layer formation.- In the following, the effect of the surface layer formation and its subsequent restructuration shall be examined more quantitatively and correlated to the half-cell cycling performance of the material. It was shown in Figure 4a that a higher $\mathrm{Li}_{2} \mathrm{MnO}_{3}$ 


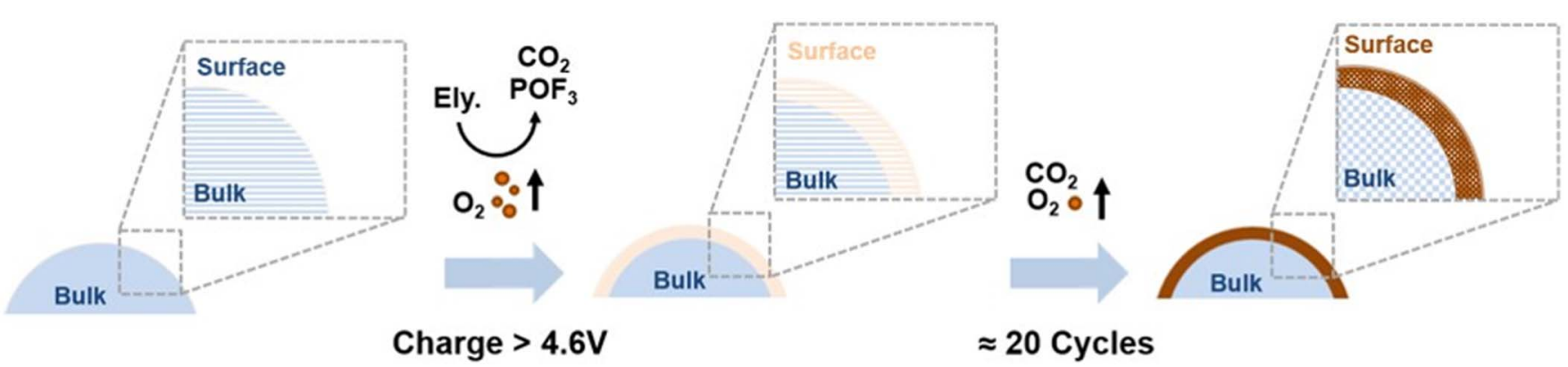

Scheme 1. Schematic presentation of the gas evolution processes and of the hypothesized mechanism of the spinel-type surface layer formation. Left panel: During the initial part of the first charge of ( $\mathrm{HE}$ )-NCMs, surface impurities are decomposed at potentials below $4.6 \mathrm{~V}$, accompanied by $\mathrm{CO}_{2}$ evolution. Upon charging to $\geq 4.6 \mathrm{~V}, \mathrm{O}_{2}$ is released from the oxide lattice, also forming $\mathrm{CO}_{2}$ by interaction of reactive oxygen (surface) species with the electrolyte. This leads to the formation of an oxygen deficient layered surface structure. Right panel: Over $\approx 20$ subsequent charge/discharge cycles, the initially formed surface layer is converted into a resistive spinel-type surface layer. Furthermore, cation migration in the bulk material, happening independently of the $\mathrm{O}_{2}$ release from the near-surface regions, leads to the observed voltage fading over extended cycling, evidence for which is reported in a previous study. ${ }^{35}$

content and thus also a higher oxygen release leads to faster capacity fading. Furthermore, the corresponding dQ/dV plots for the charging cycles show the evolution of a new phase between $2.0 \mathrm{~V}$ and $3.15 \mathrm{~V}$ (shaded areas in Figure 5), the capacitive contribution of which increases mainly during the first 20 cycles and is the larger the higher the $\mathrm{Li}_{2} \mathrm{MnO}_{3}$ content of the material and the higher the oxygen release. As it is has been shown in the literature that spinel structures delithiate at roughly the same potential, ${ }^{47,48}$ it is conceivable that the lithiation capacity between $2.0 \mathrm{~V}$ and $3.15 \mathrm{~V}$ corresponds to the lithiation of a spinel-like surface layer formed by the structural surface transformation upon oxygen release. If this were true, part of the capacity fading should be ascribable to the lower capacity of the resulting spinel vs. the initially present layered surface phase. To examine this hypothesis, Table V compares the measured capacity losses between cycle 3 and cycle $48\left(\mathrm{Q}_{\text {loss }}^{\text {meas. }}\right)$ of the three HE-NCMs (data from Figure $\left.4 \mathrm{a}\right)$ with the charge capacities between $2.0 \mathrm{~V}$ and $3.15 \mathrm{~V}$ for cycle 48 (referred to as $\mathrm{Q}_{\text {spinel }}^{\text {meas }}$ ) that correspond to the capacities under the shadowed areas in Figure 5c.

To quantitatively evaluate this hypothesis that the lower capacity of the spinel surface layer formed by oxygen release can be attributed to the observed capacity loss, we estimate the capacity contributions from the layered bulk structure of the $\operatorname{HE}-\mathrm{NCM}\left(\mathrm{Q}_{\text {layered }}^{\text {est. }}\right)$ and that of the surface spinel layer formed over cycling $\left(\mathrm{Q}_{\text {spinel }}^{\text {est. }}\right)$. The capacity of the former can be estimated by taking the observed capacity of the HENCMs after the two activation cycles $(\approx 250 \mathrm{mAh} / \mathrm{g}$ in the third cycle, see Figure 4), at which point the spinel-layer has not yet been formed, and multiplying it with the remaining fraction of layered material, using the value of the mol\% of spinel estimated by the OEMS data (taken from Table IV, Model II):

$$
\mathrm{Q}_{\text {layered }}^{\text {est. }}=\left(1-\mathrm{x}_{\text {spinel }}\right) \bullet 250 \mathrm{mAh} / \mathrm{g}
$$

Similarly, assuming the theoretical reversible capacity of a spinel to be roughly $140 \mathrm{mAh} / \mathrm{g},{ }^{47}$ the estimated capacity of the surface layer after surface restructuration can be calculated by multiplying the mol\% of spinel (taken from Table IV, Model II) with the theoretical capacity of a spinel:

$$
\mathrm{Q}_{\text {spinel }}^{\text {est. }}=\mathrm{x}_{\text {spinel }} \bullet 140 \mathrm{mAh} / \mathrm{g}
$$

Thus, the capacity fade caused by the formation of a surface spinel layer $\left(\mathrm{Q}_{\text {loss }}^{\text {est. }}\right)$ would correspond to the difference between the initially observed capacity of the HE-NCMs $(\approx 250 \mathrm{mAh} / \mathrm{g})$ and subtracting the estimated capacity contributions from the remaining layered bulk structure and the surface spinel layer:

$$
\mathrm{Q}_{\text {loss }}^{\text {est. }}=250 \mathrm{mAh} / \mathrm{g}-\left(\mathrm{Q}_{\text {layered }}^{\text {est. }}+\mathrm{Q}_{\text {spinel }}^{\text {est. }}\right)
$$

In Table $\mathrm{V}$, the actually measured values of $\mathrm{Q}_{\text {loss }}^{\text {mes. (from Figure } 4 \text { ) }}$ and $\mathrm{Q}_{\text {spinel }}^{\text {meas. }}$ (Figure 5) are compared with their estimated values derived from the OEMS measurements $\left(\mathrm{O}_{2}+\mathrm{CO}_{2}\right.$ from Model II, see Table IV). The striking agreement between the measured and estimated capacity losses $\left(\mathrm{Q}_{\text {loss }}^{\text {meas. }}\right.$ vs. $\left.\mathrm{Q}_{\text {loss }}^{\text {est. }}\right)$ and between the measured and estimated contributions of the spinel surface layer to the capacity $\left(Q_{\text {spinel }}^{\text {meas. }}\right.$ vs. $\mathrm{Q}_{\text {spinel }}^{\text {est. }}$ ), provides strong evidence that the capacity fading of HENCMs is caused by the formation of a spinel surface layer with a lower intrinsic capacity compared to the originating layered structure.

Examination of voltage fading.-Despite the large changes in the extent of surface spinel formation and oxygen release as a function of $\mathrm{Li}_{2} \mathrm{MnO}_{3}$ content, the extent of voltage fading does seem rather independent of the $\mathrm{Li}_{2} \mathrm{MnO}_{3}$ content (see Figure 4b). Thus, we conclude that the oxygen release and the associated surface layer formation is not the main driving force for the observed voltage fading. To a smaller extent, however, it does influence the mean charge voltage, as the capacity contribution for charging the surface spinel layer at 2.0 to $\approx 3.15 \mathrm{~V}$ increases with increasing $\mathrm{Li}_{2} \mathrm{MnO}_{3}$ content (see Figure 5) and thus with increasing oxygen release (Figure 3 ). Nevertheless, since the capacity contribution from the surface spinel layer does not exceed $10 \%$ of the overall capacity (see Table V), it is not surprising that the charge voltage fading of the $0.50 \mathrm{Li}_{2} \mathrm{MnO}_{3}$ material is only insignificantly larger for the $0.50 \mathrm{Li}_{2} \mathrm{MnO}_{3}$ compared to the other materials (see Figure $4 \mathrm{~b}$ ). As oxygen release cannot be responsible for the observed voltage fading, the probable reason is that the reported

Table V. Capacity loss measured from half-cell cycling in Figure $4\left(Q_{l o s s}^{\text {meas. }}\right)$ and capacity loss estimated by the amount of surface degradation

\begin{tabular}{|c|c|c|c|c|}
\hline \multirow[b]{2}{*}{$\mathrm{Li}_{2} \mathrm{MnO}_{3}$} & \multicolumn{2}{|c|}{ Capacity loss $[\mathrm{mAh} / \mathrm{g}]$} & \multicolumn{2}{|c|}{ Capacity surface layer $[\mathrm{mAh} / \mathrm{g}]$} \\
\hline & $Q_{\text {loss }}^{\text {meas }}$ & $Q_{\text {loss }}^{\text {est. }}$ & $Q_{\text {spinel }}^{\text {meas }}$ & $Q_{\text {spinel }}^{\text {est. }}$ \\
\hline 0.33 & 7 & 6 & 8 & 7 \\
\hline 0.42 & 15 & 12 & 18 & 15 \\
\hline 0.50 & 28 & 22 & 25 & 28 \\
\hline
\end{tabular}
$\left(Q_{\text {loss }}^{\text {est }}\right)$, as shown in Table IV. These values can be compared to the measured capacity of the spinel layer from Figure 5 ( $\left.Q_{\text {spinel }}^{\text {meas. }}\right)$ and to the estimated capacity of the spinel layer ( $\left.Q_{\text {spinel }}^{\text {est. }}\right)$ according to Equations 14-16. 
transition metal movement within the layered bulk material leads to changes of the thermodynamic potentials, at least at low C-rates, where differences in impedance are less critical: reversible transition metal movement leading to the charge/discharge voltage hysteresis and irreversible transition metal movement to voltage-fading. $35,38,46$

At higher C-rates, the substantially larger impedance growth for more the more lithium-rich materials (see Figure 6) may lead to overall lower mean discharge voltages. Unfortunately, it is not possible to quantify this effect on the basis of the impedances shown only for $50 \%$ SOC in Figure 6, as the impedance for HE-NCMs is known to be strongly dependent on SOC..$^{14}$

Effect of different $\mathrm{Li}_{2} \mathrm{MnO}_{3}$ contents onto full-cell performance.-So far, all data discussed in this study focused onto the half-cell performance and the structural changes of the cathode material. While the capacity and capacity fading in half-cells at low/moderate C-rate is mainly limited by the real capacity of the cathode material (impedance effects usually being small) and by cycling induced capacity changes, the performance of full-cells at faster C-rates can in addition be limited by impedance growth, cell balancing, and the loss of active lithium (also via crosstalk effects between the anode and the cathode). Therefore, in order to predict the performance of actual battery cells with a new cathode material, full-cell data are required, whereby also the amount of electrolyte added to the cells plays an important role. Wagner et al. showed that the mass ratio of electrolyte to cathode active material in large-scale commercial cells is on the order of $\mathrm{m}_{\text {ely }}: \mathrm{m}_{\mathrm{CAM}} \approx 1: 3,{ }^{56}$ which is typically $\approx 10$-fold lower than what is used in coin cells (or other small-scale test cells). In the following, in order to most closely approach the value in large-scale cells, we used a ratio of $\mathrm{m}_{\text {ely }}: \mathrm{m}_{\mathrm{CAM}}$ $\approx 1: 1$, the lowest ratio with which we could still obtain reproducible coin cell data.

From Figure 9a it can be seen that the capacity fading for all the HE-NCM materials is similar over the first 50 cycles. After 50 cycles, the discharge capacity at $1 \mathrm{C}$ ranges from $200-220 \mathrm{mAh} / \mathrm{g}$, only $\approx 20 \mathrm{mAh} / \mathrm{g}$ lower than the discharge capacity at $\mathrm{C} / 5$ in the half-cells (see Figure 4a). Beyond 50 cycles, the full-cell capacity of the material with $0.50 \mathrm{Li}_{2} \mathrm{MnO}_{3}$ content (blue line in Figure 9a) actually surpasses that of the other materials, which can be explained by the larger lithium reservoir produced in the graphite anode (see Table II).

The mean discharge voltage observed in full-cells (Figure $9 b$ ) follows the same order as in half-cells (Figure 4b), being the lower the higher $\mathrm{Li}_{2} \mathrm{MnO}_{3}$ content. Over the first 50 cycles, all materials exhibit $\mathrm{a} \approx 2$-fold higher mean discharge voltage-fading at $1 \mathrm{C}$ in full-cells compared to that in half-cells at $\mathrm{C} / 5$, which most likely is due to the significant impact of the cathode impedance on cell voltage at the high current densities at $1 \mathrm{C}\left(2.1 \mathrm{~mA} / \mathrm{cm}^{2}\right)$, so that an increase in the charge transfer resistance over extended cycling will have a larger effect on voltage-fading. Finally, one of the most important factors for the practical assessment of the materials is their specific discharge energy, i.e. the product of capacity and mean discharge potential, shown in Figure 9c. It demonstrates that essentially identical specific discharge energy values and fading rates are observed for all HE-NCMs, independent of their $\mathrm{Li}_{2} \mathrm{MnO}_{3}$ content. Nevertheless, regarding their practical application in large-scale cells, the $0.33 \mathrm{Li}_{2} \mathrm{MnO}_{3}$ material is superior, as it would release the least amount of gas during the first two formation cycles, namely $\approx 0.25 \mathrm{mmol}_{\mathrm{O} 2+\mathrm{CO} 2} / \mathrm{g}_{\mathrm{AM}}$ ( $\left.\equiv 6 \mathrm{~cm}^{3} \mathrm{O} 2+\mathrm{CO} 2 / \mathrm{g}_{\mathrm{AM}}\right)$ for the $0.33 \mathrm{Li}_{2} \mathrm{MnO}_{3}$ material vs. $\approx 0.90$ $\mathrm{mmol}_{\mathrm{O} 2+\mathrm{CO} 2} / \mathrm{g}_{\mathrm{AM}}\left(\equiv 22 \mathrm{~cm}^{3} \mathrm{O} 2+\mathrm{CO} 2 / \mathrm{g}_{\mathrm{AM}}\right)$ for the $0.50 \mathrm{Li}_{2} \mathrm{MnO}_{3}$ material (see Figure 3).

$\mathrm{O}_{2}$ and $\mathrm{CO}_{2}$ evolution of $\mathrm{HE}-\mathrm{NCM} v \mathbf{v s}$. NCM.-Jung et al. recently reported a similar oxygen release from stoichiometric NCM materials, also caused by a chemical spinel transformation at the particle surface. ${ }^{10}$ The onset potential for oxygen evolution and the amount of oxygen release was shown to be strongly dependent on the nickel content of the material, whereby oxygen release was always observed at $\approx 80 \%$ SOC. To compare the oxygen release from HE-NCM and stoichiometric NCM, the here used base NCM material for the HE-
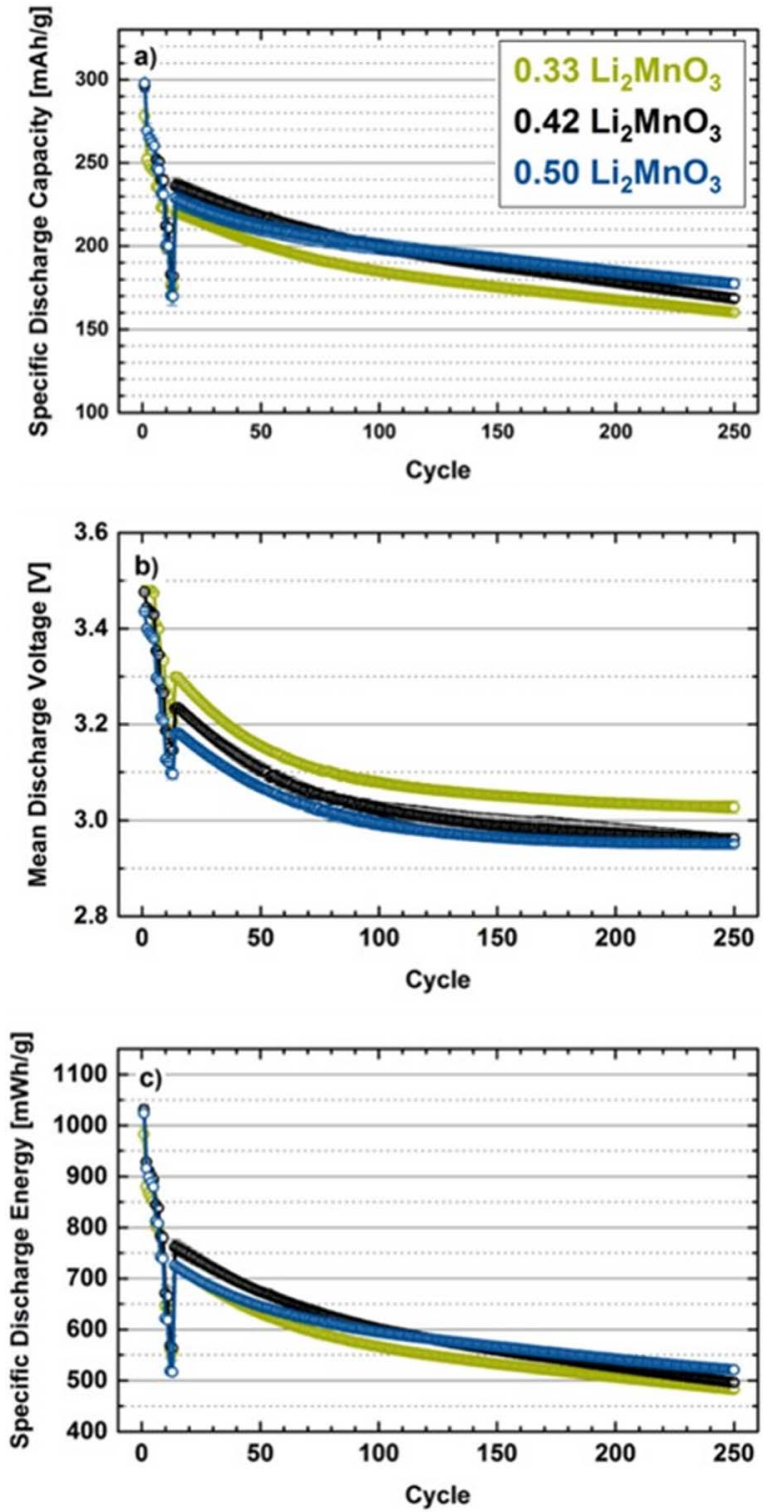

Figure 9. Electrochemical cycling of the different HE-NCM compositions in full-cells at $25^{\circ} \mathrm{C}$, using a graphite anode, $14 \mu \mathrm{L}$ of FEC:DEC (2:8 g:g) with $1 \mathrm{M} \mathrm{LiPF}_{6}$ electrolyte with a proprietary co-solvent $\left(\mathrm{m}_{\text {ely }}: \mathrm{m}_{\mathrm{CAM}} \approx 1: 1\right)$ and a Celgard separator. The first activation cycles were carried out at $\mathrm{C} / 15$ to $4.7 \mathrm{~V}$ where the potential was held for $1 \mathrm{~h}$ and then the cell was discharged at $\mathrm{C} / 15$ to $2.0 \mathrm{~V}$. This was followed by a rate test (up to $3 \mathrm{C}$ ) between $2.0 \mathrm{~V}$ and $4.6 \mathrm{~V}$, while further cycling was carried out at $\mathrm{C} / 2$ charge $(+1 \mathrm{~h} \mathrm{CV})$ rate and $1 \mathrm{C}$ discharge between $2.0 \mathrm{~V}$ and $4.6 \mathrm{~V}$. (a) Shows the specific discharge capacity as a function of the cycle number, (b) shows the mean discharge voltages, and (c) shows the specific discharge energy referenced to the cathode active material weight. All data points represent the average of at least two independent measurements and the error bars reflect the maximum and minimum of the measured values.

NCMs (referred to as $0.00 \mathrm{Li}_{2} \mathrm{MnO}_{3} \bullet 1.00 \mathrm{LiMeO}_{2}$ in Table I) was also investigated by OEMS. Results for the gas evolution of the base NCM are shown in Figure 10, using the same procedure that was used for the HE-NCMs (see Figure 3). In contrast to the HE-NCMs, oxygen evolution already occurred at $4.52 \mathrm{~V}$ and is also mainly observed during the first cycle. Furthermore, a strong increase in the $\mathrm{CO}_{2}$ evolution was observed at the onset of oxygen evolution in the first cycle; in the second cycle, $\mathrm{CO}_{2}$ evolution was observed at the potential where $\mathrm{O}_{2}$ evolution had started in the first cycle, analogous to the OEMS data with the HE-NCM materials (see Figure 3 ). These data strongly suggest that oxygen release and subsequent surface restructuration for HE-NCM and stochiometric NCM materials follow 


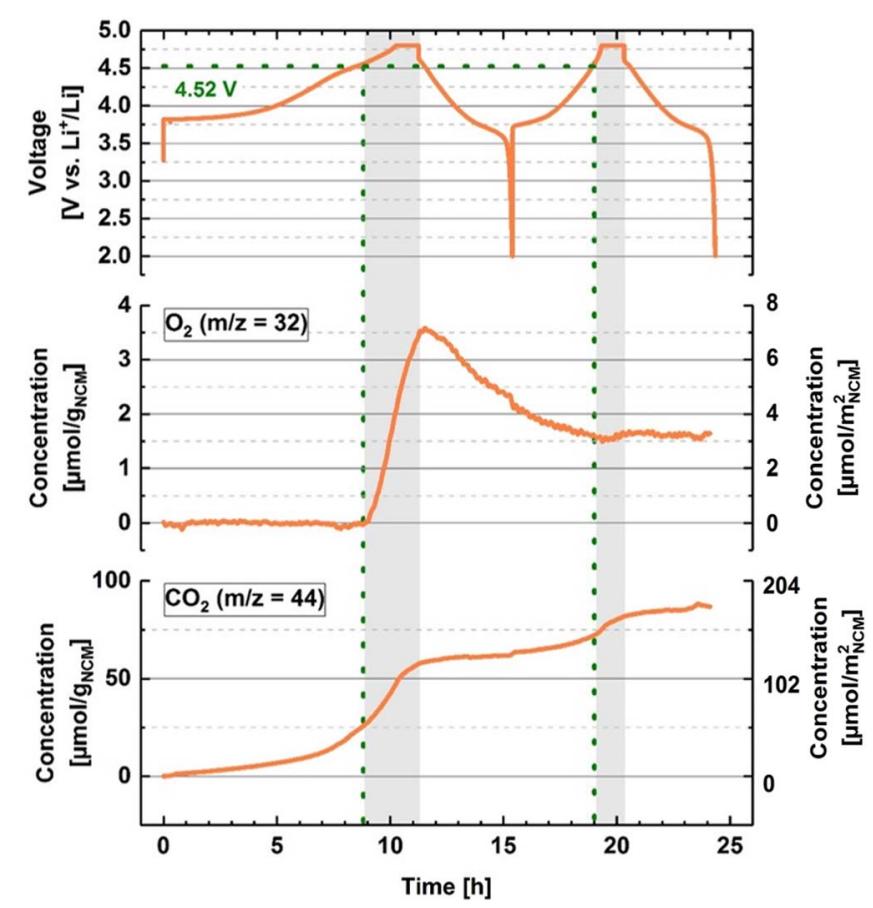

Figure 10. OEMS measurements for the stochiometric $\mathrm{NCM}\left(0.00 \mathrm{Li}_{2} \mathrm{MnO}_{3}\right.$ - $1.00 \mathrm{LiMeO}_{2}$, see Table I, using the same cell setup and procedure as in Figure 3 for the HE-NCMs. Upper panel: charge/discharge voltage vs. time; middle/lower panel: evolution of the concentrations of concomitantly evolved $\mathrm{O}_{2} / \mathrm{CO}_{2}$ given in units of either $\mu \mathrm{mol} / \mathrm{g}_{\mathrm{AM}}$ (left axes) or $\mu \mathrm{mol} / \mathrm{m}^{2} \mathrm{AM}$ (right axes).

very similar mechanisms, in both cases leading to reactions of lattice oxygen with the electrolyte via a surface reaction ${ }^{57}$ and/or the reaction with released singlet oxygen. ${ }^{55}$ In addition, for the stochiometric base $\mathrm{NCM}$ ("0.00 $\mathrm{Li}_{2} \mathrm{MnO}_{3}$ ") and the $0.33 \mathrm{Li}_{2} \mathrm{MnO}_{3} \mathrm{HE}-\mathrm{NCM}$, the SOC at which oxygen evolution can be observed is essentially identical $(\approx 77 \%)$. Increasing the $\mathrm{Li}_{2} \mathrm{MnO}_{3}$ content however leads to oxygen evolution even at lower SOCs, namely at $\approx 72 \%$ for the $0.42 \mathrm{Li}_{2} \mathrm{MnO}_{3}$ material and at $\approx 69 \%$ for the $0.50 \mathrm{Li}_{2} \mathrm{MnO}_{3}$ material (all HE-NCM data from Figure 3). The shift of the onset of oxygen evolution to lower $\mathrm{SOC}$ values with increasing $\mathrm{Li}_{2} \mathrm{MnO}_{3}$ content indicates that the near-surface region of the material becomes less stable with increasing $\mathrm{Li}_{2} \mathrm{MnO}_{3}$ content, which is consistent with the observation that the thickness of the restructured surface layer increases with increasing $\mathrm{Li}_{2} \mathrm{MnO}_{3}$ content (see Figure 8), extending all the way into the bulk for the $0.50 \mathrm{Li}_{2} \mathrm{MnO}_{3}$ material.

To compare the total amount of oxygen evolved from the different HE-NCMs and the stoichiometric NCM, all data for the gas evolution were normalized to the respective BET surface area (see Table I), as the surface area of the stoichiometric NCM was more than ten times smaller than that of the HE-NCMs. For the $\mathrm{O}_{2}$ quantification, the $\mathrm{O}_{2}$ evolved during the first two cycles is shown; for $\mathrm{CO}_{2}$ quantification, the $\mathrm{CO}_{2}$ evolved above the oxygen onset potential during the first and the second cycle is shown (gray areas in Figure 3 and Figure 10). Figure 11 shows that the $0.33 \mathrm{Li}_{2} \mathrm{MnO}_{3}$ material evolves even less oxygen than the stoichiometric base NCM material, while a further increase of the $\mathrm{Li}_{2} \mathrm{MnO}_{3}$ content substantially increases the released amount of oxygen. Surprisingly, the surface normalized amount of evolved $\mathrm{CO}_{2}$ for the three HE-NCM materials is essentially identical, despite the largely different oxygen release, while the base $\mathrm{NCM}$ releases much higher amounts of $\mathrm{CO}_{2}$. This observation could be rationalized by either one of the following hypotheses: i) at the high absolute oxygen release rates from the high surface area HE-NCMs, the surface reaction between lattice oxygen and the electrolyte could become rate-limiting, so that a significant fraction of the oxygen is released as molecular oxygen without any

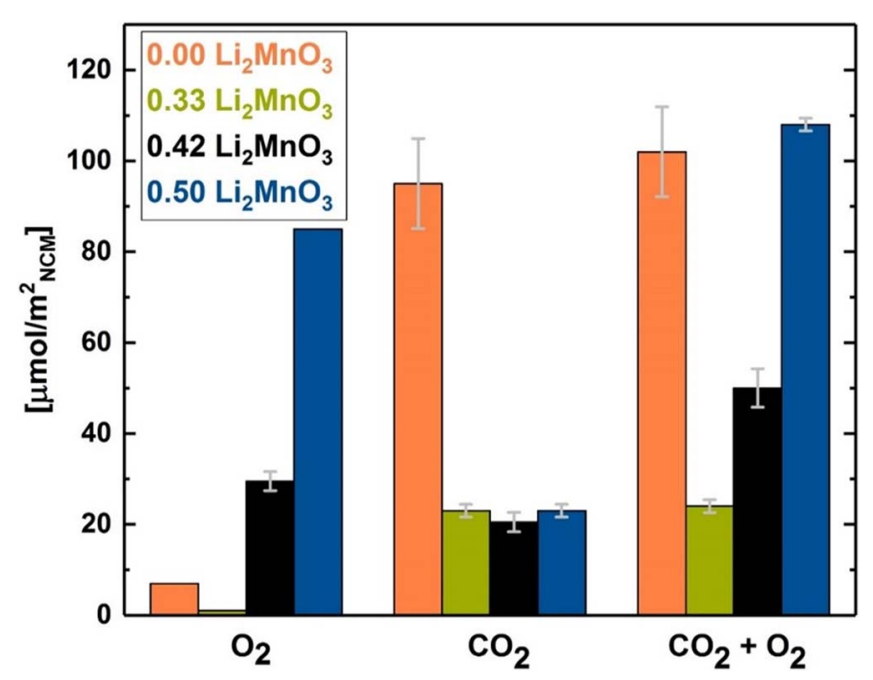

Figure 11. $\mathrm{O}_{2}$ and $\mathrm{CO}_{2}$ (after oxygen onset) evolution of the first two cycles are shown for the three different materials from Figure $3(0.33,0.42$ and 0.50 $\mathrm{Li}_{2} \mathrm{MnO}_{3}$ ), data for $0.00 \mathrm{Li}_{2} \mathrm{MnO}_{3}$ are from Figure 10. Total gas amounts were quantified during the first and the second cycle above the oxygen onset potential, depicted by the gray areas in Figure 3 and Figure 10. The error bars shown in this figure are derived from two separate OEMS measurements for each material.

further reaction with the electrolyte; or, ii) oxygen released from the surface at high rates as singlet oxygen ${ }^{55}$ could form gas bubbles, in which reactive singlet $\mathrm{O}_{2}$ can decay to triplet oxygen within the gas phase, while the reaction of singlet oxygen with the electrolyte to $\mathrm{CO}_{2}$ would be limited to the gas/electrolyte interface. It is also conceivable that the latter may be influenced by particle morphology, whereby the hierarchical structure of the HE-NCM particles (consisting of primary agglomerates composed of smaller primary particles with interstitial pores) could lead to a formation/trapping of oxygen gas bubbles in contrast to NCM particles which have no internal void volume.

Despite the so far not clearly understood differences in the evolved $\mathrm{CO}_{2} / \mathrm{O}_{2}$ ratios for the different materials, the comparison of the total amount of lattice oxygen released from the materials (represented by the sum of $\mathrm{CO}_{2}+\mathrm{O}_{2}$; see right-hand-side bars in Figure 11) suggests that low amounts of $\mathrm{Li}_{2} \mathrm{MnO}_{3}$ added to the base NCM can increase the active material stability at high SOCs. This stabilization may explained by the compensation of repulsive forces between the transition metal layers at low lithium content, produced by the loss of lithium from the transition metal layer, thereby creating vacancies within the transition metal layers. These repulsive forces would furthermore be reduced by the reported reversible oxygen redox ${ }^{26,32,33}$ whereby it is conceivable that the creation of vacancies in the transition metal layer during the first activation cycle is responsible for enabling oxygen redox processes. ${ }^{38}$ However, increasing the $\mathrm{Li}_{2} \mathrm{MnO}_{3}$ content leads to an increased lithium occupation in the transition metal layer in the pristine material ${ }^{58}$ that will be extracted during the first activation charge, leading to a destabilization of the surface at increasingly lower SOCs, as was discussed above.

\section{Conclusions}

In this study, we systematically compared HE-NCM materials with different amounts of $\mathrm{Li}_{2} \mathrm{MnO}_{3}$ using on-line electrochemical mass spectrometry (OEMS), high-resolution transmission electron microscopy (HRTEM) and electrochemical characterization methods, in order to understand the oxygen release as well as its influence on the active material structure and the electrochemical performance. We could show quantitatively that the half-cell capacity loss at low C-rates during the first 50 cycles can be ascribed to the formation of a surface spinel layer which can be estimated from the gas 
evolution. HRTEM shows that the surface layer thickness increases with increasing $\mathrm{Li}_{2} \mathrm{MnO}_{3}$ content, hereby the thickness was in excellent agreement with the layer thickness estimated from the OEMS experiments, except the $0.50 \mathrm{Li}_{2} \mathrm{MnO}_{3}$ material, for which spinel formation occurs all the way into the bulk of the material.

The oxygen release and the total gas release differ vastly for the different materials, even though the full-cell initial capacity, the capacity retention and the voltage fading are rather similar for all materials, which ends up in full-cell energies and energy fading that are essentially identical over 250 cycles. However, for practical applications in large-scale cells the initial gas evolution is a critical factor where the material with $0.33 \mathrm{Li}_{2} \mathrm{MnO}_{3}$ outperforms the other materials, having a nearly 4 times lower initial gas evolution $\left(6 \mathrm{~cm}^{3} / \mathrm{g}_{\mathrm{CAM}}\right)$ compared to the $0.50 \mathrm{Li}_{2} \mathrm{MnO}_{3}$ material $\left(22 \mathrm{~cm}^{3} / \mathrm{g}_{\mathrm{CAM}}\right)$. Furthermore, the increase in impedance is more critical for the $0.50 \mathrm{Li}_{2} \mathrm{MnO}_{3}$ compared to the other materials, leading to improved rate performance for lower $\mathrm{Li}_{2} \mathrm{MnO}_{3}$ contents.

\section{Acknowledgment}

This work was supported by BASF SE within its BASF SE Battery Research Network. The authors want gratefully acknowledge A. Freiberg, K. Kleiner and R. Jung for their contribution to this work and for the very fruitful discussions.

\section{ORCID}

Tobias Teufl (D) https://orcid.org/0000-0001-5889-5204

\section{References}

1. J. B. Goodenough and K. S. Park, J. Am. Chem. Soc., 135(4), 1167 (2013).

2. D. Andre, S.-J. Kim, P. Lamp, S. F. Lux, F. Maglia, O. Paschos, and B. Stiaszny, J. Mater. Chem. A, 3(13), 6709 (2015).

3. K. Mizushima, P. Jones, P. Wiseman, and J. B. Goodenough, Mat. Res. Bull., 15(6), 783 (1980).

4. Z. Lu, D. D. MacNeil, and J. R. Dahn, Electrochem. Solid-State Lett, 4(12), A200 (2001).

5. J. Choi and A. Manthiram, J. Electrochem. Soc., 152(9), A1714 (2005).

6. I. Belharouak, Y. K. Sun, J. Liu, and K. Amine, J. Power Sources, 123(2), 247 (2003).

7. M.-H. Kim, H.-S. Shin, D. Shin, and Y.-K. Sun, J. Power Sources, 159(2), 1328 (2006).

8. R. Jung, M. Metzger, F. Maglia, C. Stinner, and H. A. Gasteiger, J. Phys. Chem. Lett., 8(19), 4820 (2017)

9. D. Streich, C. Erk, A. Guéguen, P. Müller, F.-F. Chesneau, and E. J. Berg, J. Phys Chem. C, 121(25), 13481 (2017).

10. R. Jung, M. Metzger, F. Maglia, C. Stinner, and H. A. Gasteiger, J. Electrochem. Soc., 164(7), A1361 (2017).

11. M. M. Thackeray, S.-H. Kang, C. S. Johnson, J. T. Vaughey, R. Benedek, and S. A. Hackney, J. Mat. Chem., 17(30), 3112 (2007).

12. J. R. Croy, M. Balasubramanian, K. G. Gallagher, and A. K. Burrell, Acc. Chem. Res., 48(11), 2813 (2015).

13. S. R. Gowda, D. W. Dees, A. N. Jansen, and K. G. Gallagher, J. Electrochem. Soc., 162(7), A1374 (2015).

14. T. Teufl, D. Pritzl, S. Solchenbach, H. A. Gasteiger, and M. Mendez, manuscript in preparation.

15. A. R. Armstrong, M. Holzapfel, P. Novák, C. S. Johnson, S.-H. Kang, M. M. Thackeray, and P. G. Bruce, J. Am. Chem. Soc., 128(26), 8694 (2006).

16. C. S. Johnson, J. S. Kim, C. Lefief, N. Li, J. T. Vaughey, and M. M. Thackeray, Electrochem. Commun., 6(10), 1085 (2004)

17. F. La Mantia, F. Rosciano, N. Tran, and P. Novák, J. Appl. Electrochem., 38(7), 893 (2008).

18. P. Lanz, H. Sommer, M. Schulz-Dobrick, and P. Novák, Electrochim. Acta, 93, 114 (2013).

19. Z. Lu, L. Y. Beaulieu, R. A. Donaberger, C. L. Thomas, and J. R. Dahn, J. Electrochem. Soc., 149(6), A778 (2002).

20. Z. Lu and J. R. Dahn, J. Electrochem. Soc., 149(7), A815 (2002).
21. D. Mohanty, J. Li, S. C. Nagpure, D. L. Wood, and C. Daniel, MRS Energy \& Sustainability, 2, (2015).

22. N. Yabuuchi, K. Yoshii, S. T. Myung, I. Nakai, and S. Komaba, J. Am. Chem. Soc., 133(12), 4404 (2011).

23. A. Guéguen, D. Streich, M. He, M. Mendez, F. F. Chesneau, P. Novák, and E. J. Berg, J. Electrochem. Soc., 163(6), A1095 (2016).

24. D. Streich, A. Guéguen, M. Mendez, F. Chesneau, P. Novák, and E. J. Berg, $J$. Electrochem. Soc., 163(6), A964 (2016).

25. B. Strehle, K. Kleiner, R. Jung, F. Chesneau, M. Mendez, H. A. Gasteiger, and M. Piana, J. Electrochem. Soc., 164(2), A400 (2017).

26. K. Luo, M. R. Roberts, R. Hao, N. Guerrini, D. M. Pickup, Y.-S. Liu, K. Edström, J. Guo, A. V. Chadwick, L. C. Duda, and P. G. Bruce, Nat. Chem., 8, 684 (2016).

27. H. Koga, L. Croguennec, M. Menetrier, K. Douhil, S. Belin, L. Bourgeois, E. Suard, F. Weill, and C. Delmas, J. Electrochem. Soc., 160(6), A786 (2013).

28. H. Koga, L. Croguennec, M. Ménétrier, P. Mannessiez, F. Weill, and C. Delmas, J. Power Sources, 236, 250 (2013).

29. C. Genevois, H. Koga, L. Croguennec, M. Ménétrier, C. Delmas, and F. Weill, $J$. Phys. Chem. C, 119(1), 75 (2014).

30. R. Petibon, L. Madec, D. W. Abarbanel, and J. R. Dahn, J. Power Sources, 300, 419 (2015).

31. S. Muhammad, H. Kim, Y. Kim, D. Kim, J. H. Song, J. Yoon, J.-H. Park, S.-J. Ahn, S.-H. Kang, and M. M. Thackeray, Nano Energy, 21, 172 (2016).

32. E. McCalla, A. M. Abakumov, M. Saubanère, D. Foix, E. J. Berg, G. Rousse, M.-L. Doublet, D. Gonbeau, P. Novák, G. Van Tendeloo, D. R., and J. M. Tarascon, Science, 350(6267), 1516 (2015).

33. D. H. Seo, J. Lee, A. Urban, R. Malik, S. Kang, and G. Ceder, Nat. Chem., 8(7), 692 (2016).

34. H. Koga, L. Croguennec, M. Ménétrier, P. Mannessiez, F. Weill, C. Delmas, and S. Belin, J. Phys. Chem. C, 118(11), 5700 (2014).

35. K. Kleiner, B. Strehle, A. R. Baker, S. J. Day, C. C. Tang, I. Buchberger, F.-F. Chesneau, H. A. Gasteiger, and M. Piana, Chem. Mater, (2018), in press,.

36. G. Assat, C. Delacourt, D. A. D. Corte, and J.-M. Tarascon, J. Electrochem. Soc., 163(14), A2965 (2016).

37. B. Qiu, M. Zhang, Y. Xia, Z. Liu, and Y. S. Meng, Chem. Mat., 29(3), 908 (2017).

38. W. E. Gent, K. Lim, Y. Liang, Q. Li, T. Barnes, S.-J. Ahn, K. H. Stone, M. McIntire, J. Hong, J. H. Song, Y. Li, A. Mehta, S. Ermon, T. Tyliszczak, D. Kilcoyne, D. Vine, J.-H. Park, S.-K. Doo, M. F. Toney, W. Yang, D. Prendergast, and W. C. Chueh, Nat. Commun., 8(1), 2091 (2017).

39. N. Tsiouvaras, S. Meini, I. Buchberger, and H. A. Gasteiger, J. Electrochem. Soc., 160(3), A471 (2013)

40. J. R. Croy, K. G. Gallagher, M. Balasubramanian, B. R. Long, and M. M. Thackeray, J. Electrochem. Soc., 161(3), A318 (2013).

41. J. Choi and A. Manthiram, Electrochem. Solid-State Letters, 8(8), C102 (2005).

42. I. Buchberger, S. Seidlmayer, A. Pokharel, M. Piana, J. Hattendorff, P. Kudejova, R. Gilles, and H. A. Gasteiger, J. Electrochem. Soc., 162(14), A2737 (2015).

43. S. E. Renfrew and B. D. McCloskey, J. Am. Chem. Soc., 139(49), 17853 (2017).

44. R. Jung, P. Strobl, F. Maglia, C. Stinner, and H. A. Gasteiger, manuscript in preparation.

45. J. R. Croy, K. G. Gallagher, M. Balasubramanian, Z. Chen, Y. Ren, D. Kim, S.-H. Kang, D. W. Dees, and M. M. Thackeray, J. Phys. Chem. C, 117(13), 6525 (2013).

46. M. Sathiya, A. M. Abakumov, D. Foix, G. Rousse, K. Ramesha, M. Saubanere, M. L. Doublet, H. Vezin, C. P. Laisa, A. S. Prakash, D. Gonbeau, G. VanTendeloo, and J. M. Tarascon, Nat. Mater., 14(2), 230 (2015).

47. M. M. Thackeray, Prog. Solid State Chem., 25, 1 (1997).

48. P. G. Bruce, A. R. Armstrong, and L. Gitzendanner, J. Mat. Chem., 9, 193 (1998)

49. J. C. Burns, A. Kassam, N. N. Sinha, L. E. Downie, L. Solnickova, B. M. Way, and J. R. Dahn, J. Electrochem. Soc., 160(9), A1451 (2013).

50. D. Pritzl, A. Bumberger, M. Wetjen, J. Landesfeind, S. Solchenbach, and H. Gasteiger, manuscript in preparation.

51. J. Landesfeind, D. Pritzl, and H. A. Gasteiger, J. Electrochem. Soc., 164(7), A1773 (2017).

52. S.-M. Bak, K.-W. Nam, W. Chang, X. Yu, E. Hu, S. Hwang, E. A. Stach, K.-B. Kim, K. Y. Chung, and X.-Q. Yang, Chem. Mat., 25(3), 337 (2013).

53. S. M. Bak, E. Hu, Y. Zhou, X. Yu, S. D. Senanayake, S. J. Cho, K. B. Kim, K. Y. Chung, X. Q. Yang, and K. W. Nam, ACS Appl. Mater. Interfaces, 6(24), 22594 (2014).

54. D. Mohanty, S. Kalnaus, R. A. Meisner, K. J. Rhodes, J. Li, E. A. Payzant, D. L. Wood, and C. Daniel, J. Power Sources, 229, 239 (2013).

55. J. Wandt, A. T. S. Freiberg, A. Ogrodnik, and H. A. Gasteiger, Materials Today, 2018, in press,.

56. F. T. Wagner, B. Lakshmanan, and M. F. Mathias, J. Phys. Chem. Lett., 1(14), 2204 (2010).

57. T. M. Østergaard, L. Giordano, I. E. Castelli, F. Maglia, B. K. Antonopoulos, Y. Shao-Horn, and J. Rossmeisl, J. Phys. Chem. C, 122(19), 10442 (2018).

58. H. Liu, Y. Chen, S. Hy, K. An, S. Venkatachalam, D. Qian, M. Zhang, and Y. S. Meng, Adv. Energy Mat., 6(7), 1502143 (2016). 